\title{
RNA Modifications and RNA Metabolism in Neurological Disease Pathogenesis
}

\author{
Biswanath Chatterjee ${ }^{1}$, Che-Kun James Shen ${ }^{1, *}$ and Pritha Majumder ${ }^{2, *}$ \\ 1 Institute of Molecular Biology, Academia Sinica, Taipei City 115, Taiwan; biswa@gate.sinica.edu.tw \\ 2 Institute of Molecular Medicine, College of Medicine, National Cheng Kung University, Tainan 704, Taiwan \\ * Correspondence: ckshen@gate.sinica.edu.tw (C.-K.J.S.); z11001021@ncku.edu.tw (P.M.)
}

Citation: Chatterjee, B.; Shen, C.-K.J.; Majumder, P. RNA Modifications and RNA Metabolism in Neurological Disease Pathogenesis. Int. J. Mol. Sci. 2021, 22, 11870. https://doi.org/ $10.3390 /$ ijms222111870

Academic Editor: Claudia Martini

Received: 31 August 2021

Accepted: 26 October 2021

Published: 1 November 2021

Publisher's Note: MDPI stays neutral with regard to jurisdictional claims in published maps and institutional affiliations.

Copyright: (c) 2021 by the authors. Licensee MDPI, Basel, Switzerland. This article is an open access article distributed under the terms and conditions of the Creative Commons Attribution (CC BY) license (https:// creativecommons.org/licenses/by/ $4.0 /)$.

\begin{abstract}
The intrinsic cellular heterogeneity and molecular complexity of the mammalian nervous system relies substantially on the dynamic nature and spatiotemporal patterning of gene expression. These features of gene expression are achieved in part through mechanisms involving various epigenetic processes such as DNA methylation, post-translational histone modifications, and noncoding RNA activity, amongst others. In concert, another regulatory layer by which RNA bases and sugar residues are chemically modified enhances neuronal transcriptome complexity. Similar RNA modifications in other systems collectively constitute the cellular epitranscriptome that integrates and impacts various physiological processes. The epitranscriptome is dynamic and is reshaped constantly to regulate vital processes such as development, differentiation and stress responses. Perturbations of the epitranscriptome can lead to various pathogenic conditions, including cancer, cardiovascular abnormalities and neurological diseases. Recent advances in next-generation sequencing technologies have enabled us to identify and locate modified bases/sugars on different RNA species. These RNA modifications modulate the stability, transport and, most importantly, translation of RNA. In this review, we discuss the formation and functions of some frequently observed RNA modificationsincluding methylations of adenine and cytosine bases, and isomerization of uridine to pseudouridineat various layers of RNA metabolism, together with their contributions to abnormal physiological conditions that can lead to various neurodevelopmental and neurological disorders.
\end{abstract}

Keywords: RNA modifications; RNA metabolism; brain development; neurodegenerative diseases; neurodevelopmental disorders

\section{Introduction}

RNA is subjected to multifaceted regulatory processes to sustain diversity and complexity at the organismal and molecular levels. It has evolved to participate in diverse cellular processes owing to its capability to couple enzymatic activity with the storage and transfer of information. Upon being transcribed, the nascent RNA is subjected to various processing mechanisms, collectively termed post-transcriptional processing, that ultimately confer it with its information storage/transfer and regulatory functions. Posttranscriptional processing of eukaryotic RNA typically includes $5^{\prime}$ capping, intron removal or splicing, and addition of a $3^{\prime}$ polyadenylated tail. Another crucial mechanism of posttranscriptional RNA modification is the chemical modification of RNA bases and sugar residues on the RNA backbone. Similar to chemical modification of DNA cytosine residues that constitute part of the epigenome, chemical modifications of RNA, the "epitranscriptome", adds another regulatory layer to organismal transcriptome-wide complexity. The functional impact of the epitranscriptome manifests in almost all tissues, but it is most apparent in regulating complex organs such as the brain. It is both transcriptomic and epitranscriptomic diversity that endows the nervous system with its complexity, with the latter altering various layers of RNA metabolism. RNA metabolism encompasses diverse processes including biogenesis, transport, splicing, stabilization, storage, and 
translation. Many recent studies have highlighted how dysregulation of RNA transport, splicing, stabilization, translation, or miRNA/tRNA biogenesis contributes to age-related neurodegenerative diseases [1] and neurodevelopmental disorders [2,3]. Precise spatial and temporal expression of various proteins is essential for appropriate brain development, which is achieved by proper accomplishment of RNA stabilization, transport and translation [4]. Even in the adult brain, RNA metabolism is one of the most crucial mechanisms for maintaining correct brain functions and learning-based memory consolidation [4]. Although different aspects of RNA metabolism contribute to neurodegenerative diseases and neurodevelopmental disorders, RNA-binding proteins (RBPs) play important roles in both kinds of disease pathogenesis [2,5].

According to the MODOMICS database, $\sim 170$ different RNA modifications have been identified to date, yet only a few have been well characterized and specifically linked to neurological disease [6]. RNA modifications are widely regarded as a regulatory tool for fine-tuning gene expression, acting beyond epigenomic regulatory mechanisms. Tremendous advancements in next-generation sequencing technologies have identified various RNA modifications at the single nucleotide level, which can be linked to mechanisms underlying tissue-specific and age-dependent gene expression profiles or to the pathophysiology of complex diseases such as cancer [5]. Functionally, three groups of protein factors-known as "writers", "readers" and "erasers" - are involved in drafting the epitranscriptome, with writers and erasers possessing substrate-specific enzymatic activities. Together, these are known as RNA-modifying proteins (RMPs). Writers are the enzymes or effecters of RNA modification marks, whereas erasers are responsible for removing such marks. Readers recognize specific RNA modification marks, bind at that site, and activate downstream pathways, often altering RNA metabolism. Mutations and changes in the abundance of RMPs have been linked to various conditions, such as infertility and obesity, as well as neurodegenerative and neurodevelopmental diseases and cancer $[7,8]$.

However, though RNA modification likely alters RNA metabolism, it remains enigmatic how such modifications contribute to neurodevelopmental and neurodegenerative diseases. In this review, we explore several exciting studies reporting the effects of different RNA modifications on various aspects of RNA metabolism and evaluate links between those modifications and a variety of neurological diseases.

\section{RNA Metabolism-Associated Neurological Disease Mechanisms}

\section{1. $m$ RNA Splicing}

Introns of pre-mRNAs are removed and exons are joined in a process called premRNA splicing to form mature mRNAs, and this process is regulated by several cis-acting elements and via formation of a multi-protein complex termed the spliceosome [9]. The involvement of different cis-acting elements alters exon recognition by spliceosomes, giving rise to alternatively spliced mRNAs from the same mRNA transcript. Alternative splicing not only contributes to diversity among species, but also enables tissue-specific expression of differentially spliced products to perform different functions [10]. mRNA splicing is emerging as a crucial mechanism for maintaining neuronal transcriptome complexity, shaping neuronal structure, function, and differentiation processes [10-12]. Perturbations of the essential association between cis-acting elements and splicing motifs result in splicing defects, potentially resulting in neurological disorders or neurodegenerative disease [13].

Effect on neurodevelopmental diseases: Approximately $1.4 \%$ of autism spectrum disorder (ASD) cases are caused by splicing defects [14]. Changes in splicing patterns of several mRNAs related to the PTEN signaling pathway have been observed in a murine model of ASD [15]. Animal models of neurodevelopmental disorders have also revealed alterations to the expression of position-dependent splicing factors. For example, neurooncologic ventral antigen (NOVA) and RNA-binding protein FOX (RBFOX) paralogs are positive regulators of exon inclusions during splicing of mRNAs linked to brain development, spine formation and neurite growth, and their downregulation has been observed in post-mortem brain tissue of autistic patients. Polypyrimidine tract-binding protein 1 
(PTBP1) is a negative regulator of exon inclusion, and it is highly expressed during early embryonic development when it facilitates cells to enter the neuronal lineage. Abnormal (low) expression of this protein has been linked to schizophrenia-associated seizures [9].

Effect on neurodegenerative diseases: Alternative splicing also regulates the expression of different isoforms of $\alpha$-synuclein, the main component of Lewy bodies and a hallmark of Parkinson's disease (PD) [16]. Similarly, the ratio of alternatively spliced products of the tau gene product MAPT [13], namely 3R tau (formed upon exclusion of exon 10) and $4 \mathrm{R}$ tau (formed upon inclusion of exon 10) contribute to another well-known neurodegenerative disorder, Alzheimer's disease (AD). Some recent studies have also highlighted alternative splicing and splicing defects as contributory mechanisms of different neurodegenerative diseases [17]. For instance, a TDP-43 mutation linked to ALS alters the splicing function of TDP-43, resulting in changed RNAs and contributing to early manifestation of the disease [18]. Splicing defects have been established as one of the major contributors for Huntington's disease (HD) [19].CAG repeat expansion in SCA type 6-linked genes induce altered mRNA splicing patterns that result in accumulations of disease-causing polyglutamine-containing protein [20].

\section{2. mRNA Alternative Polyadenylation}

The alternative polyadenylation (APA) of mRNAs is the use of multiple polyadenylation sites in primary transcripts and in conjunction with alternative splicing. APA expands cellular transcriptomic diversity by generating distinct mRNA isoforms [21]. Depending on the location of polyadenylation sites (PASs), APA can be classified into two types: UTR-APA and coding region-APA (CR-APA) [22]. The presence of APA sites in 3'-UTRs of mRNAs generates transcript isoforms with the same coding region but with different lengths of $3^{\prime}$-UTR regions, thus giving rise to distinct interactions of mRNA isoforms with RNAbinding proteins and non-coding RNAs like microRNA and lncRNAs [21]. On the other hand, CR-APA directly affects the coding region and leads to the generation of proteins with different C-termini $[23,24]$. APA is found in all eukaryotes, and in mammals, about $70 \%$ of all mRNA-encoding genes undergo APA [25-27]. APA events can be tissue-specific to a great extent; for example, in the case of $3^{\prime}$-UTR APA isoforms, distal PASs are enriched in neurons, while blood cells and testis tissue favor the use of proximal PASs [28,29]. The functional consequences of APA sites in $3^{\prime}$-UTR of pre-mRNAs are diverse. For example, $3^{\prime}$-UTR-APAs participate in post-transcriptional gene regulation through various methods, such as modification of mRNA stability, translation, nuclear export and cellular localization. The influence of $3^{\prime}$-APA upon stability of mRNAs can be exemplified through altered effects of miRNA functions. For example, about $10 \%$ of all miRNAs targeting two cell types can be influenced by expression of APA isoforms [30]. Another way through which $3^{\prime}$-UTR APA events can modulate mRNA stability is differential binding of various RNA binding factors as well as lncRNAs that can affect the mRNA decay process [21]. The localization of mRNAs can also be influenced by 3'-UTR APA events, which is best exemplified in the case of $B D N F$ transcripts, where the short isoform is restricted to the cell body while the long isoform is predominantly found in the dendrites [31]. Lastly, 3'-UTR APA events can directly influence protein localization, as evidenced in the case of proteins like CD47, CD44, $\alpha 1$ integrin (ITGA1) and TNF receptor superfamily member 13C (TNFRSF13C) [32]. CR-APA events are known to contribute to protein diversification, as seen in the case of transcripts encoded by genes like calcitonin-related polypeptide- $\alpha$ (CALCA) and immunoglobulin $\mathrm{M}$ heavy chain $(\operatorname{IgM})$ [21]. CR-APA can also repress gene expression by generating severely truncated transcripts through utilization of PAS proximal to the promoter, as observed in the case of transcripts encoded by the mammalian polyadenylation factor cleavage stimulation factor $77 \mathrm{kDa}$ subunit (CstF-77) gene [33]. 
Effect of neurodevelopmental diseases: Neuronal commitment at the early stages of neurodevelopment is heavily influenced by the transcriptome repertoire of neural stem cells. During neurodevelopment, APA contributes significantly to the specification of neuronal lineage in association with other mechanisms such as microRNA networks, alternative splicing, non-sense mediated RNA decay, etc., that shape the transcriptome diversity of neural stem cells. APA events are known to be enriched in specific neuronal cell types [34,35]. Additionally, single-cell RNA sequencing data analysis identified cell type-specific APA landscapes in different GABAergic interneurons in the mouse cerebral cortex. Interestingly, genes with cell type-specific APA events are enriched in biological processes like synaptic vesicle recycling, neurotransmitter release, ion transport etc., which implies a significant role of APA in synaptic communication and neuronal identity determination [36]. Furthermore, the role of APA during early stages of neurodevelopment, such as the commitment and differentiation of neural progenitors, has been investigated by Grassi et al. where transcriptome-wide changes of $3^{\prime}$-UTR lengths were observed during differentiation of mouse-adherent neural stem cells into GABAergic inhibitory neurons [37]. A group of studies have linked APA events and $3^{\prime}$-UTR in specific genes like $\mathrm{MeCP}$, FMR1 to disorders with autistic phenotypes such as Rett syndrome, Fragile X-associated syndrome, autism, schizophrenia and other psychiatric diseases [38-42]. Since ASDs have been correlated with aberrations of calcium signaling, the dysregulation of APA events in the autistic brains, as found by analyzing RNA sequencing data from publicly available databases, are linked with dysregulation of calcium ion homeostasis by Szkop et al. [43]. The effect of APA in the regulation of MeCP2 protein levels and concomitant development of neuropsychiatric diseases has been studied by Gennarino et al., where copy-number variation of the NUDT21 gene that encodes a subunit of pre-mRNA cleavage factor Im is reported to regulate the length of $\mathrm{MeCP} 2$ transcript $3^{\prime}$-UTR [44].

Effect of neurodegenerative diseases: The ability of APA events to generate transcripts with varying lengths of $3^{\prime}$-UTR gives rise to their intimate association with the regulation of gene expression. Since significant alterations of gene expression have been observed in neurodegenerative disorders [45,46], APA can be viewed as a potentially important regulatory mechanism operating during the development and progression of different neurodegenerative diseases. Analysis of RNA sequencing data from AD, PD and ALS patients and matched healthy controls, available in public databases, revealed diseasespecific changes of APA profiles in a subset of genes among each disease [47]. Although this study found APA profile changes in relatively small subset of genes, and affected genes differ among RNA-sequencing datasets, they found, in all three disease-associated datasets, overrepresentation of genes associated with protein turnover and mitochondrial function. Usage of the distal PAS site in $\alpha$-synuclein mRNA generates an extended transcript isoform which is shown to be associated with PD development, and the presence of this extended $3^{\prime}$-UTR promotes accumulation of the $\alpha$-synuclein protein, which gets redirected away from the synaptic terminal towards mitochondria [48]. Genome-wide usage of proximal PAS within $3^{\prime}$-UTR regions or PAS within introns leads to transcriptome-wide shortening of $3^{\prime}$-UTR regions, and that may underlie the development of neurological disorders like oculopharyngeal muscular dystrophy (OPMD) [49]. The effect of APA events on the regulation of the localization and stability of mRNAs is conclusively exemplified in the case of mRNAs encoded by the gene huntingtin ( $\mathrm{Htt}$ ), involved in the development of HD. The huntingtin mRNA has two isoforms differing in the length of $3^{\prime}$-UTR. The abundance of $H t t$ isoforms differs among cerebellum, motor cortex, fibroblasts and neural stem cells from patients and controls. Additionally, two isoforms differ with respect to their localization, the length of their poly-A tail, their half-lives and their binding sites for miRNA- and RNA-binding proteins. Moreover, the mRNA $3^{\prime}$-UTR isoform change is not restricted to $\mathrm{Htt} ; 11 \%$ of alternatively polyadenylated genes in the HD motor cortex undergo changes with respect to the abundance of their mRNA isoforms [50]. Reduced expression of TDP43 has been associated with the utilization of a intronic cryptic polyadenylation site of the stathmin-2 gene in ALS and frontotemporal dementia (FTD). This results in reduced 
expression of the stathmin-2 gene, which is a hallmark of ALS-FTD [51]. Finally, alternative polyadenylation of human tau gene has been associated with binding of mir-34 family members of miRNAs and expression of tau mRNA isoforms [52].

\section{3. $m R N A$ Transport and Translation}

Owing to the presence of extended neuronal processes, such as long axons and dendrites, it requires more energy and time to transport proteins on demand from the soma to distal parts of neurons. However, mRNAs are transported along neurites together with ribosomes and all the translation machineries, so mRNAs are ready to be translated in different parts of neurons [53]. Recent investigations have found that ribosomes are assembled at the distal end of axons instead of being formed from proximally translated ribosomal proteins and transported as part of mRNP complexes to the distal site [54,55]. Moreover, various mRNAs can be transported together, yet remain translationally repressed. RBPs play important roles in both mRNA transport and translational repression. Dysregulation of dendritic mRNA transport/translation causes aberrant spine formation and dendritic structural anomalies, as well as learning memory impairments, that are symptoms of neurodevelopmental disorders [56]. Axonal transport and translation of mRNAs are required to maintain the structure of axons and their function in conducting nerve impulses [57]. Clearly, if axonal mRNA transport/translation is impaired, neuronal functions will be severely compromised, diminishing neuronal survival, as observed for many neurodegenerative diseases [58]. A new mode of translation dysregulation has come to surface through the recent discovery of repeat-associated non-AUG (RAN) translation [59]. This mode of translation gets activated due to tandem repeat expansion beyond the threshold during repeat expansion diseases and causes translation from all three reading frames. These mis-translated proteins are accumulated in diseased tissues to manifest disease phenotypes [60].

Effect on neurodevelopmental diseases: An impressive body of work has uncovered how translational dysregulation of mRNAs is linked to ASD and Fragile X syndrome (FXS) [61]. Most of the experimentally-validated mRNAs (e.g., Map1b, GluR1, Rac1, CamKII, Shank3, Gabrb1, among others) are targets of the RBP Fragile X mental retardation protein (FMRP) and are associated with synaptic structural anomalies and dysfunction, as well as impairments of long-term memory formation [61-63]. Furthermore, genetic mutations of several core translation regulatory proteins, e.g., RPL10, eIF4E, UPF3B, GW182, CYFIP1, Caprin1, eIF2B, and PTEN, have also been linked to ASD and other neurodevelopmental disorders such as infantile epilepsy, mental retardation, schizophrenia, attention deficit hyperactivity disorder (ADHD) and many more. More than 1000 such genes have been included in the Simons Foundation Autism Research Initiative (SFARI) database (https:/ / gene.sfari.org/; accessed date July 2021). Further research is in progress to establish the molecular mechanisms underlying translational dysregulation of the mRNA targets of these proteins [64].

Effect on neurodegenerative diseases: Patients suffering spinal muscular atrophy (SMA) exhibit reduced binding of survival motor neurons (SMN) to small nuclear RNA (snRNAs) because of genetic mutation-driven impairment of SMN protein stability, resulting in abnormal snRNA trafficking and maturation [65]. In contrast, ALS-linked mutations enhance stress granule formation or cause aberrant clearance, resulting in larger RNAprotein assemblies [66]. These examples indicate that either hyper- or hypo-assembly of mRNPs causing aberrant transport of mRNAs can lead to many neurodegenerative diseases [65]. Atypical transport/translation of mRNAs associated with the muscleblind-like (MBLN) group of proteins causes myotonic dystrophy (DM) [67]. RAN translation in the c9orf 72 gene harboring $\mathrm{G} 4 \mathrm{C} 2$ repeat expansion mutations at intron 1 has been established as the main cause of ALS and FTLD diseases [68]. In SCA31, expansion of a TGGAA repeat in the BEAN1 transcript causes accumulation of pentapeptide repeat protein translated from all three reading frames using a similar mechanism. Moreover, a UGGAA repeat containing an abnormally structured RNA, known as an RNA foci, sequesters RBPs, affecting their functions and thus contributing to disease phenotypes [69]. RNA foci and the activation of RAN translation are also implicated in SCA8, HD and many other triplet repeat disor- 
ders [70,71]. Recently, mutant huntingtin protein was shown to stall ribosomes, thereby affecting the translation of several mRNAs (including $M f s d 10$ and $P p b p$ ) that contribute to HD progression [72]. Deviant axonal transport of mRNAs associated with TDP-43 (Map1b, Nefl) or with FUS (e.g., Fosb) contributes to ALS and frontotemporal lobar degeneration (FTLD) [73,74]. Interestingly, translational activation of CyclinD1 and TDP-43 mRNAs via Ataxin2-mediated polyadenylation in association with the Poly-A binding protein PAPD4 can induce TDP-43 proteinopathies, such as the Tau aggregation typical of FTLD, ALS, and $\mathrm{AD}[75,76]$. Together, this evidence establishes dysregulated mRNA transport/translation as a crucial factor in several neurological diseases.

\section{4. mRNA Stability}

To maintain RNA homeostasis, mRNAs transcribed inside the nucleus decay through various biological processes directed by cis-acting elements. Exonucleases and endonucleases contribute to these decay processes [77]. Methylation capping at the $5^{\prime}$ untranslated region (UTR) and polyadenylation at the $3^{\prime}$-UTR protect mRNAs from degradation by these nucleases. Gene expression levels are dependent on mRNA stability, which is measured by the half-lives of mRNAs [78]. mRNA half-life can be increased or decreased by diverse mechanisms [79]. Alternatively spliced mRNAs can harbor or exclude cis-acting elements or enable alternative polyadenylation, thereby regulating the stability of the mRNA [80].

Effect on neurodevelopmental diseases: The Hu/Elav group of proteins exert an important role in exon inclusion and differential polyadenylation to alter the stability of mRNAs such as Bdnf and Nf1, thus regulating neuronal differentiation and function [81]. HuD-null mice exhibit sensory and motor neuron defects [82]. Moreover, neuronal Elav-like (nELAVL) protein has been associated with ASD [83]. Reduced expression of the mRNA stability-related protein RBFOX1 has also been linked to ASD [4]. Recent experimental evidence has further confirmed that FMRP can alter ASD-related mRNA stability to counter Ataxin2-mediated changes in gene expression under different kinds of cellular stress [84].

Effect on neurodegenerative diseases: nELAVL-mediated changes in mRNA stability have also been implicated in neurodegenerative diseases such as AD and PD [85]. A recent study reported that Ataxin2 endows stability on its mRNA target TDP-43, with this function being dependent on its poly-Q domain. Expansion of the poly-Q domain of Ataxin2 alters TDP-43 mRNA stability, resulting in tau protein aggregation and ALS pathogenesis [86]. Another RBP, RBFOX, stabilizes mRNAs encoding synaptic transmissions, and its dysregulation has been linked to AD [87]. Proteins primarily known to regulate other forms of RNA metabolism are also known to alter RNA stability. For instance, TDP-43 participates in stabilizing $\beta$-adducin (Add2) mRNA. This phenomenon is predicted to be associated with ALS and FTLD diseases, though its exact mechanism is not yet understood [88]. Thus, different RBPs work together to maintain mRNA/protein homeostasis in the cell by changing mRNA stability and translation. Any failure in this coordinated effort can induce neurological pathogenicity. 


\section{5. miRNA Biogenesis}

Micro-RNAs (miRNAs) are small non-coding regulatory RNAs that post-transcriptionally silence specific mRNAs, representing another form of temporal gene expression control. These miRNAs are involved in fine-tuning gene expression required for neural development, structure and function, so aberrant miRNA activity can induce neurological disease [89]. miRNA profiling has revealed that a considerable number of miRNAs are expressed in the hippocampus of the adult brain in an activity-dependent manner. For instance, miR-132 is expressed under KCl- or DHPG-driven neural activation, and miR-212 is regulated via the CREB activation pathway [90,91].

Effect on neurodevelopmental disease: miRNA biogenesis has been implicated in synaptic plasticity and long-term memory formation [89]. Dysregulated miRNA synthesis and maturation contribute to ASD, intellectual disability, and schizophrenia [92].

Effect on neurodegenerative diseases: Interestingly, the progression of neurodegenerative diseases also appears to be dependent on the differential expression of miRNAs. Post-mortem AD brains display significantly different miRNA expression profiles compared to age-matched controls $[93,94]$. Specifically, reduced expression of miR-9 in the hippocampus and miR-107 in the cortex were observed in AD brains, and this feature was linked to aberrant expression of BACE1, Sirtuin1, and PSEN1. In contrast, miR-7, miR-153, miR-34b, miR-224, and miR-379 regulate accumulation and aggregation of $\alpha$-synuclein, a hallmark of PD [95]. ALS-linked inflammation has been linked to dysregulation of miR-577, miR-155, and let-7 [96]. Moreover, miRNA expression and functions may also be partially responsible for other neurodegenerative diseases such as HD and MD [97,98].

Different RNA metabolisms described above are also shown in Table 1. 
Table 1. Dysregulated RNA metabolism in neurological diseases.

\begin{tabular}{|c|c|c|c|c|c|}
\hline Disease Type & $\begin{array}{l}\text { Altered RNA Metabolism } \\
\text { Pathway }\end{array}$ & RBP(s) Involved & Mechanisms & Neurological Disease(s) & References \\
\hline \multirow{8}{*}{ Neuro developmental diseases } & Splicing, Translation & CPEB4 & $\begin{array}{l}\text { Missplicing of CPEB4 causes reduced inclusion of } \\
\text { a neuron-specific microexon, leading to } \\
\text { diminished expression of the Cpeb4 transcript that } \\
\text { activates translation of mRNAs via } \\
\text { polyadenylation under normal conditions }\end{array}$ & ASD & [99] \\
\hline & \multirow{5}{*}{$\begin{array}{l}\text { Splicing Translation, mRNA } \\
\text { stability, miRNA biogenesis }\end{array}$} & \multirow{5}{*}{$\begin{array}{l}\text { RBFOX1, RBFOX2 (RBM9), } \\
\text { RBFOX3 (Neun) }\end{array}$} & $\begin{array}{l}\text { RBFOX } 1 \text { binds to the } 3^{\prime} \text {-UTR of its target mRNAs } \\
\text { and regulates: }\end{array}$ & \multirow{5}{*}{ ASD } & \multirow{5}{*}[23,100-102]{} \\
\hline & & & $\begin{array}{l}\text { - } \quad \text { Splicing of Camk } 2 d \text { and Camk } 2 g \text { mRNAs; } \\
\text { - } \quad \text { Stability of Camk2a, Camk } 2 b, \text { Camk } 4 \text {, and } \\
\text { Ppp3r1 mRNAs; } \\
\text { - } \quad \text { translational regulation by }\end{array}$ & & \\
\hline & & & RBFOX2 and RBFOX3 (repression) & & \\
\hline & & & - $\quad$ miRNA biogenesis. & & \\
\hline & & & $\begin{array}{l}\text { Altered splicing of RBFOX family proteins } \\
\text { impairs their control of gene expression }\end{array}$ & & \\
\hline & Transport, Translation & FMRP & $\begin{array}{l}\text { CGG repeat expansion beyond } 200(>200) \text { at the } \\
5^{\prime} \text {-UTR of } F M R 1 \text { affects protein expression, } \\
\text { resulting in dysregulated spatio-temporal } \\
\text { transport/translation of dendritic mRNAs }\end{array}$ & FXS & [64] \\
\hline & APA & NUDT21 & $\begin{array}{l}\text { Elevated amount of NUDT21, a subunit of } \\
\text { pre-mRNA cleavage factor Im, due to copy } \\
\text { number variation causes abnormal usage of } \\
\text { polyadenylation sites, resulting in the generation } \\
\text { of an inefficiently translated long isoform of } \\
\text { MeCP2 protein. }\end{array}$ & Neuropsychia tric disease & [44] \\
\hline
\end{tabular}


Table 1. Cont.

\begin{tabular}{|c|c|c|c|c|c|}
\hline Disease Type & $\begin{array}{l}\text { Altered RNA Metabolism } \\
\text { Pathway }\end{array}$ & RBP(s) Involved & Mechanisms & $\begin{array}{l}\text { Neurological } \\
\text { Disease(s) }\end{array}$ & References \\
\hline \multirow{9}{*}{$\begin{array}{l}\text { Neuro degenerative } \\
\text { diseases }\end{array}$} & Splicing & PRPF8 & $\begin{array}{l}\text { Mutated Huntingtin (HTT) traps PRPF8 (a splicing factor) to cause CREB1 } \\
\text { mis-splicing }\end{array}$ & HD & [18] \\
\hline & Splicing & MBNL family proteins & $\begin{array}{l}\text { RNA corresponding to expanded microsatellite repeats in DMPK traps } \\
\text { MBNL-family proteins, impairing their normal function in splicing }\end{array}$ & $\mathrm{DM}$ & [103] \\
\hline & Translation & ATAXIN-2 & $\begin{array}{l}\text { CAG expansion in the reading frame of ATAXIN-2 causes loss of protein } \\
\text { function that, under normal conditions, acts as an mRNA translation } \\
\text { activator via polyadenylation }\end{array}$ & SCA2, ALS & [75] \\
\hline & $\begin{array}{l}\text { RAN Translation, } \\
\text { Abnormal RNA structure (RNA } \\
\text { foci) }\end{array}$ & Matrin-3 & $\begin{array}{l}\text { GGGGCC repeat expansion mutation in the C9orf } 72 \text { gene causes } \\
\text { sequestration of Matrin- } 3 \text { at the RNA foci and RAN translated peptides } \\
\text { and loss of function of Matrin-3 }\end{array}$ & FTLD, ALS & [104] \\
\hline & $\begin{array}{l}\text { mRNA stability, Splicing, } \\
\text { Translation }\end{array}$ & nELAVL & $\begin{array}{l}\text { nELAVL regulates disease-specific splicing of the pre-mRNAs Picalm and } \\
\text { Bin1 by incorporating exons } 13 \text { and } 6 a \text {, respectively. The proteins } \\
\text { corresponding to these spliced isoforms have been implicated in trafficking } \\
\text { of amyloid precursor protein }\end{array}$ & $\mathrm{AD}$ & [105] \\
\hline & $\begin{array}{c}\text { Transport, Translation, miRNA } \\
\text { biogenesis }\end{array}$ & TDP-43 & $\begin{array}{l}\text { - TDP-43-mediated axonal transport/translation of mRNAs such as } \\
\text { Nefl and Map1b is adversely affected in diseased neurons expressing } \\
\text { disease-specific mutant TDP-43; } \\
\text { TDP-43 has been implicated in FMRP co-regulation of mRNA } \\
\text { transport/translation; } \\
\text { - Nuclear localization of TDP- } 43 \text { is affected in diseased neurons, } \\
\text { altering its RNA-binding ability and the fate of target RNAs; } \\
\text { Normal TDP-43 function in cleaving certain pre-miRNAs via Drosha } \\
\text { binding in the nucleus is impaired. }\end{array}$ & FTLD, ALS & {$[63,106-108]$} \\
\hline & Transport, Translation & FUS & $\begin{array}{l}\text { Normal FUS functions such as axonal transport/translation of mRNAs are } \\
\text { adversely impacted in diseased neurons. } \\
\text { Under disease conditions, the altered intracellular localization of FUS } \\
\text { disrupts its functions as an RBP }\end{array}$ & FTLD, ALS & [109] \\
\hline & Splicing, miRNA biogenesis & hnRNPs, MBNL1 & $\begin{array}{l}\text { mRNA corresponding to shorter CGG repeat expansions }(<200) \text { in the } \\
5^{\prime} \text { UTR of } F M R 1 \text { sequester many RBPs, e.g., hnRNPs and MBNL1 }\end{array}$ & $\begin{array}{l}\text { Fragile } X \text {-associated } \\
\text { tremor/ataxia } \\
\text { syndrome (FXTAS) }\end{array}$ & [110] \\
\hline & APA & $\alpha$-synuclein & $\begin{array}{l}\text { Presence of an extended } 3^{\prime} \text {-UTR region in } \alpha \text {-synuclein transcript impacts } \\
\text { accumulation of } \alpha \text {-synuclein protein that is redirected away from synaptic } \\
\text { terminals towards mitochondria }\end{array}$ & $\mathrm{PD}$ & [48] \\
\hline
\end{tabular}




\subsection{Roles for RBPs in RNA Metabolism and Neurological Diseases}

Various mechanisms of RNA metabolism temporally regulate the protein expression responsible for brain development, structure and function. RBPs fine-tune RNA metabolism, resulting in further complexities of gene expression in different neuronal parts [5]. Expression-mediated RBP functions may be countered by other RBPs, thereby maintaining a balance of RNA metabolism and gene expression for neurons in different parts of the brain. Dysregulated RBP functioning and enrichment can severely perturb such control mechanisms, resulting in neurodevelopmental or neurodegenerative diseases (summarized in Table 1) [111,112].

\section{RNA Modifications that Change RNA Metabolic Processes}

Despite hundreds of RNA modifications on coding and non-coding RNAs having been identified to date, only a few have been studied extensively or linked to disease. Wellstudied RNA modifications include the methylation of adenosine at position $6(\mathrm{~m} 6 \mathrm{~A}$, also known as N6-methyladenosine), N1-methyladenosine (m1A), 5-methyl cytosine (m5C), pseudouridine, and RNA editing, e.g., A-to-I (see Figure 1) [113,114].

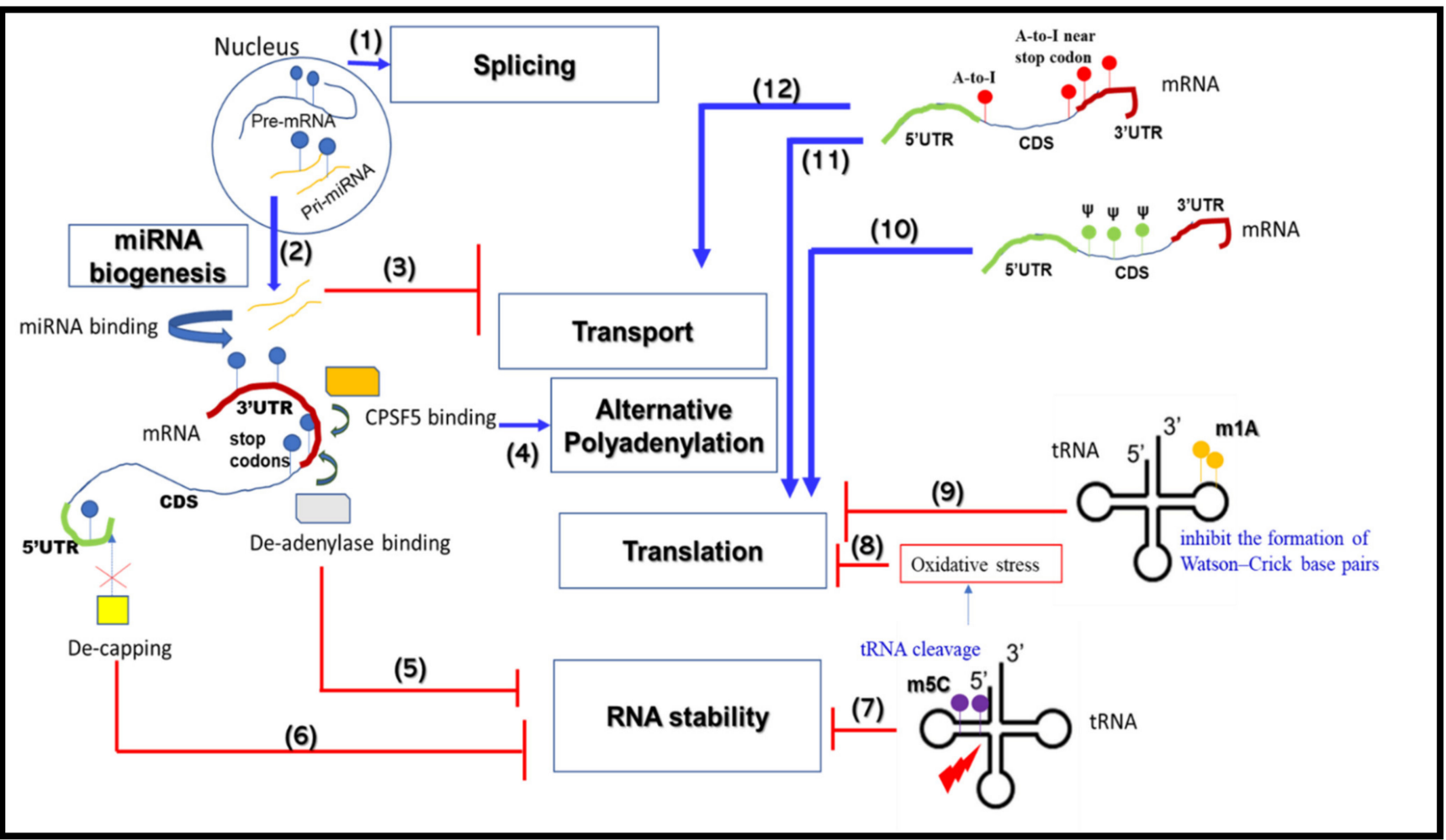

Figure 1. Illustrative model summarizing how various RNA metabolic processes are modulated by RNA modifications. Different RNA modifications, e.g., m6A, m5C, m1A, A-to-I RNA editing and pseudouridine, are represented by blue, purple, yellow, red and yellow colored pins, respectively. Various mechanisms of activation or inhibition of RNA metabolisms by RNA modifications are represented by (1) to (12), e.g., m6A modifications of pre-mRNAs (1) and miRNAs (2) facilitate splicing and miRNA biogenesis, respectively. The model shows that m6A modification of the $3^{\prime}$-UTR of mRNAs facilitates binding of miRNAs to this region and inhibits mRNA transport/translation (3). VERMA-mediated m6A modification near the $3^{\prime}$-UTR and stop codons of mRNAs facilitates alternative polyadenylation (4). Alternatively, m6A modification near the $3^{\prime}$-UTR and stop codons causes de-adenylase binding, thereby impairing stability (5). De-capping at the $5^{\prime}$-cap site with nearby m6A inhibits translation initiation and also reduces mRNA stability as a result of endonuclease activity (6). m5C modification of tRNAs induces their cleavage, thus altering RNA stability (7). Accumulations of cleaved tRNA fragments induce oxidative stress, which inhibits cellular translation (8). m1A modification impairs base pairing of tRNA-anticodons with the mRNA initiation codon, inhibiting translation initiation (9). Both A-to-I editing and pseudouridine modification alter start or stop codons of mRNAs, blocking mRNA transport/translation $(\mathbf{1 0}, \mathbf{1 1}, \mathbf{1 2})$. 


\section{1. $m 6 A$}

m6A is the most studied RNA modification in humans. It is a dynamic and reversible modification of RNA. m6A marks have been identified on mRNAs, transfer RNAs (tRNAs), ribosomal RNAs (rRNAs), non-coding RNAs (ncRNAs), circular RNAs (circRNAs), and miRNAs. On mRNAs, most m6A marks are found at the beginning of the last exons, in the 3'-UTR or near the stop codons. Methyltransferase complexes, such as METTLE3, METTLE4 and WTAP, act as writers to methylate adenosine at position 6. Demethylases such as FTO and ALKBH5 are the known erasers of m6A modification marks $[115,116]$. There are three different groups of readers that recognize m6A marks on RNAs and can alter patterns of RNA metabolism. The first group comprises heterogeneous nuclear ribonucleoprotein A2/B1 (HNRNPA2B1), which regulates splicing and miRNA processing by binding to m6A marks on certain miRNAs [117]. The second group is YTH-RNA binding domain-containing proteins, which regulate splicing, mRNA stability, translation and miRNA synthesis [114]. The third group includes insulin-like growth factor 2 mRNAbinding proteins (IGF2BPs) that recognize m6A marks in the $3^{\prime}$-UTRs of mRNAs and enhance mRNA stability $[118,119]$.

m6A modifications impact dendritic structure, spinogenesis, learning memory, neurogenesis, axon regeneration and brain development $[115,120]$. Neurological disease phenotypes arise from dysregulated m6A pathways, owing to disease-specific mutations or changes in amounts of various m6A players. Although the underlying mechanisms remain incompletely understood, RNA modifications at m6A positions have been implicated as contributing to epilepsy, intellectual disability, and schizophrenia [121]. m6A modification also plays a very important role in $\mathrm{AD}$ by altering the protein levels of transcripts responsible for disease phenotypes [122]. The m6A modifications at the $3^{\prime}$-UTR of mRNAs associated with age related disorders, e.g., AD, PD, FTLD etc., have been thought to play important mechanistic roles in manifestation of these diseases, mostly through modulation of translation of these transcripts [116,123]. Dysregulated m6A modification in other RNA metabolic processes, such as splicing, has also been implicated in neurodegenerative diseases [124]. In Table 2, we present m6A modifications and changes in RNA metabolism linked to neurological diseases.

\section{2. $m 1 A$}

Methylation of the N1 position of adenosine is another dynamic RNA modification in mammalian systems. It stalls translation elongation and prevents misincorporation of nucleotides during reverse transcription (RT) by inhibiting the formation of Watson-Crick base pairs [125]. M1A modifications primarily occur in tRNAs and rRNAs, changing their topology and modulating their protein-binding ability, stability and functioning [126]. m1A modifications have also been reported in the $5^{\prime}$-UTR (where they accelerate translation) and coding sequence (CDS, where they inhibit translation) of mRNAs [127]. The most abundant cytosolic m1A writer is the hetero-tetrameric tRNA methyltransferase TRMT6/61A. The TRMT6/61A complex adds a GUUCRA tRNA-like motif with a t-loop structure to targeted nuclear mRNAs [128]. In contrast, the homodimeric TRMT61B methyltransferase acts as an m1A writer of mitochondrial mRNAs [129]. TRMT10C, another m1A methyltransferase, is responsible for modifying the mitochondrial mRNA ND5 [130]. ALKBH3 and ALKBH1 are m1A erasers, with ALKBH3 acting to demethylate the m1A mark on mRNAs [131]. As for other RNA modifications, m1A readers play important roles in regulating RNA metabolism, triggering tissue-specific and time-dependent functions. Nine putative m1A readers have recently been identified, including ribonucleoproteins and YTH family proteins such as YTHDF3 [132]. Links between m1A marks and neurological diseases have not been well established. m1A mRNA modifications are mainly associated with modulating mRNA translation and decay, thereby likely playing important roles in appropriate brain development and function [133]. A recent study associated lack of m1A marking in mitochondrial tRNA with the rare neurodegenerative disease HSD10 [134]. 
Table 2. Effects of RNA modifications on various RNA metabolic processes and their association with neurological functions and diseases.

\begin{tabular}{|c|c|c|c|c|c|}
\hline $\begin{array}{c}\text { RNA } \\
\text { Modification }\end{array}$ & $\begin{array}{l}\text { Effect on RNA } \\
\text { Metabolism and/or } \\
\text { Protein Function }\end{array}$ & Reader/Writer/Eraser & Mechanism & $\begin{array}{c}\text { Neurological } \\
\text { Functions/Diseases }\end{array}$ & References \\
\hline \multirow{5}{*}{ m6A } & mRNA stability & $\begin{array}{l}\text { Writer: METTL3, METTL14 } \\
\text { Reader: YTHDF2, YTHDF3, } \\
\text { YTHDC2 }\end{array}$ & $\begin{array}{l}\text { Readers selectively recognize and bind G-(m6 } \\
\text { A)-C-containing mRNAs via their CTD, whereas } \\
\text { the NTD localizes mRNP complexes at the cellular } \\
\text { RNA degradation machinery }\end{array}$ & Neurogenesis & [135] \\
\hline & Splicing, Transport & Reader: YTHDC1 & $\begin{array}{l}\text { In the nucleus, this reader recognizes and binds } \\
\text { pre-mRNAs with m6A methylation marks and } \\
\text { selectively recruits SRSF3 to promote exon } \\
\text { inclusion and nuclear-to-cytoplasmic transport of } \\
\text { target mRNAs. }\end{array}$ & $\begin{array}{l}\text { Facilitates neuron survival } \\
\text { after brain injury and } \\
\text { ischemic stroke }\end{array}$ & [120] \\
\hline & Transport, Translation & Reader: YTHDF1 & $\begin{array}{l}\text { This reader recruits the mRNP complex to the } \\
\text { cellular transport and translation machinery and } \\
\text { activates protein translation }\end{array}$ & $\begin{array}{l}\text { Facilitates learning and } \\
\text { memory development }\end{array}$ & [116] \\
\hline & Translation & Eraser: FTO & $\begin{array}{l}\text { In diseased neurons, FTO is translated and } \\
\text { accumulates at axons, increasing m6A } \\
\text { demethylation and NMDAR1 expression } \\
\text { followed by neuronal apoptosis }\end{array}$ & PD & [115] \\
\hline & Translation & $\begin{array}{l}\text { Writer: METTL3 } \\
\text { Eraser: FTO }\end{array}$ & $\begin{array}{l}\text { mRNA methylation controls expression of } \\
\text { AD-related transcripts, but the underlying } \\
\text { mechanism remains obscure }\end{array}$ & $\mathrm{AD}$ & [122] \\
\hline $\mathbf{m} 1 \mathrm{~A}$ & tRNA stability/Translation & Writer: MRPP1 & $\begin{array}{l}\text { Mitochondrial tRNA methylation causes } \\
\text { stabilization of the tRNA to facilitate translational } \\
\text { initiation. In disease conditions, improper } \\
\text { processing of tRNAs results in reduced } \\
\text { mitochondrial protein synthesis }\end{array}$ & HSD10 disease & [134] \\
\hline
\end{tabular}


Table 2. Cont.

\begin{tabular}{|c|c|c|c|c|c|}
\hline $\begin{array}{c}\text { RNA } \\
\text { Modification }\end{array}$ & $\begin{array}{l}\text { Effect on RNA } \\
\text { Metabolism and/or } \\
\text { Protein Function }\end{array}$ & Reader/Writer/Eraser & Mechanism & $\begin{array}{c}\text { Neurological } \\
\text { Functions/Diseases }\end{array}$ & References \\
\hline \multirow{2}{*}{ m5C } & Translation & Writer: NSUN2 & $\begin{array}{l}\text { In the absence of tRNA methylation, } \\
\text { angiogenin-mediated tRNA cleavage causes an } \\
\text { accumulation of tRNA fragments that activate } \\
\text { stress-response pathways and impair translation }\end{array}$ & $\begin{array}{l}\text { Dubowitz-like syndrome, } \\
\text { Noonan like syndrome }\end{array}$ & [133] \\
\hline & tRNA stability/Translation & Writer: DNMT2 & $\begin{array}{l}\text { Methylation of tRNAs enhance their stability and } \\
\text { facilitate their translation } \\
\text { tRNA cleavage as a result of impaired m5C } \\
\text { methylation limits translation in diseased neurons }\end{array}$ & $\begin{array}{l}\text { Brain development and } \\
\text { neurogenesis, embryogenesis }\end{array}$ & [136-138] \\
\hline Pseudoeuridine & mRNA stability, Translation & Writer: PUS1 & $\begin{array}{l}\text { Exact mechanism not yet known. It is likely the } \\
\text { presence of pseudoeuridine reduces mRNA } \\
\text { stability and impairs translation }\end{array}$ & $\mathrm{AD}$ & [139] \\
\hline RNA editing & Transport/Translation & Writer: ADAR2 & $\begin{array}{l}\text { AMPA receptor pre-mRNA is edited by ADAR2 } \\
\text { to regulate its function. Downregulation of } \\
\text { ADAR2 causes reduced editing accompanied with } \\
\text { functional defects of AMPAR under disease } \\
\text { conditions }\end{array}$ & $\begin{array}{l}\text { Schizophrenia, mood } \\
\text { disorders }\end{array}$ & {$[140,141]$} \\
\hline
\end{tabular}




\section{3. $m 5 \mathrm{C}$}

Cytosine carbon-5 methylation (m5C) of DNA has long been considered a highly important epigenetic modification impacting diverse physiological processes such as cellular differentiation and organism development, and it has been implicated in cancers and cardiovascular abnormalities. In more recent years, m5C modification of RNAs has gained increasing attention owing to its roles in RNA transport, translation and stability [142-144]. m5C modifications have been reported for rRNAs, tRNAs, and mRNAs, as well as less abundant RNA species such as vault RNAs, small nuclear RNAs (snRNAs), enhancer RNAs, long non-coding RNAs, and miRNAs [142,145-147]. In humans, the NOL1/NOP2/SUN domain-containing family of proteins (NSUN1-7) and the DNAmethyltransferase (DNMT) homologue DNMT2 create m5C marks [148]. NSUN1, NSUN2 and NSUN5 are conserved in all eukaryotes, but other family members are only found in higher eukaryotes. Functionally, NSUN1 and NSUN5 methylate cytosine C5 of cytosolic rRNAs, whereas NSUN2, NSUN6 and DNMT2 methylate cytosolic tRNAs. NSUN2, NSUN3 and NSUN4 methylate mitochondrial RNAs at cytosine C5 [149,150]. NSUN2 can also m5C-methylate mRNAs [142]. NSUN7 regulates expression levels of target genes of the transcriptional co-activator PGC- $1 \alpha$ by regulating the stability of their respective enhancer RNAs [151]. NSUN proteins and DNMT2 are both SAM-dependent methyltransferases. Mechanistically, they differ in terms of the number of catalytic cysteines they use; whereas NSUN proteins use two catalytic cysteines, DNMT2 uses a single catalytic cysteine at the active site [152,153]. Aly/REF export factor (ALYREF) and Y-box binding protein 1 (YBX1) recognize and bind to $\mathrm{m} 5 \mathrm{C}$, and these reader proteins are involved in nucleo-cytoplasmic shuttling and stability of mRNAs [142,144]. As for C5-methylated cytosine residues in DNA, m5C modification of RNAs is also highly dynamic and can be actively demethylated by Fe (II)- and $\alpha$-ketoglutarate $(\alpha-K G)$-dependent dioxygenases such as TET1 and TET2 [154].

m5C RNA methylation impacts diverse RNA metabolic processes. For instance, eukaryotic rRNA stability is affected by the presence of m5C marks, influencing folding of essential ribosomal regions and thereby regulating translation [155]. m5C modification of tRNAs alters their structure and stability, and thus translation, as also observed for C34 methylation of yeast tRNA ${ }^{\mathrm{Leu}(\mathrm{CAA})}$ [136]. Moreover, m5C modification can affect the aminoacylation step of translation and, consequently, overall translational accuracy $[137,156]$. Recent studies of Arabidopsis thaliana and zebrafish have shown that mRNA stability is regulated by m5C modification [144,157]. In a HeLa cell line, NSUN2mediated m5C modification of mRNAs was found to enable their binding with ALYREF, an mRNA transport adaptor that facilitates nuclear export [142]. Interestingly, the effects of m5C modification on mRNA translation vary depending on the site of $\mathrm{m} 5 \mathrm{C}$ deposition; it impairs translation efficiency when it occurs in the $5^{\prime}$-UTR or CDS $[143,157,158]$, yet NSUN2-mediated m5C modification in the $3^{\prime}$-UTR enhances translation efficiency [159].

The crucial functional roles played by m5C methyltransferases in RNA metabolism imply that impaired expression of these genes may be responsible for various diseases. For example, several neurodevelopmental disorders have been linked to mutations in genes encoding NSUN proteins [160]. Deletion of NSUN2 from mice induces growth retardation and delayed/blocked tissue-specific differentiation [161,162]. In humans, a homozygous mutation of the NSUN2 gene that causes a non-synonymous substitution of glycine at position 679 with arginine results in mislocalization of the protein in the nucleolus, which has been linked to the development of autosomal-recessive intellectual disability $[163,164]$. Similarly, Dubowitz syndrome-a rare autosomal recessive disorder that clinically manifests as microcephaly, abnormal facial phenotypes, mental retardation and short stature-has been linked to a homozygous mutation in the splice acceptor site of NSUN2 exon 6 that reduces mRNA stability and NSUN2 protein levels, resulting in diminished methylation of target RNAs [165]. A recent study investigating conditional disruption of NSUN2 in the prefrontal cortex of mice observed a bidirectional change in depression-related behaviors. NSUN2 deficiency resulted in changes in 1488 proteins in 
the prefrontal cortex, together with a decline in translation efficiency associated with a glycine-codon defect. Consequently, the mice displayed impaired synaptic signaling of pyramidal neurons in the prefrontal cortex and defective contextual fear memory [166]. Disruption of NSUN2-mediated tRNA methylation causes $5^{\prime}$ regions of tRNA fragments to accumulate, impairing the generation of upper layer neurons and brain development in mice [167]. Furthermore, a loss-of-function mutation in NSUN3 has been identified in a patient suffering severe mitochondrial respiratory chain complex deficiency, characterized by combined developmental disability, microcephaly, recurrent increased lactate levels in plasma, and muscular weakness [168].

\subsection{Pseudouridine ( $\Psi)$}

Pseudouridine is a uridine isomer, and it is mostly found in non-coding RNAs such as rRNAs, tRNAs, and snRNAs. High-throughput sequencing has revealed the $\Psi$ modification in yeast and human mRNAs [169]. Two distinct mechanisms of RNA pseudouridylation have been proposed. Firstly, guide RNA-dependent pseudouridylation involves H/ACA-box small nucleolar RNAs (snoRNAs) that bind to target RNAs via sequencespecific interactions, followed by catalytic uridine modification by specific enzymes (such as dyskerin in human or Cbf5 in yeast) present in the H/ACA-box snoRNA riboneucleoprotein (snoRNP) complex. Secondly, guide RNA-independent pseudouridylation requires pseudouridine synthase (PUS) enzymes that directly catalyze conversion of uridine to $\Psi$ in their targets without any accessory RNA contribution [169-171]. PUS proteins are conserved from yeast to human and have been classified into six families. Isomerization of uridine to $\Psi$ favors base stacking, thus resulting in enhanced stability of RNA secondary structures. Moreover, the presence of $\Psi$ in several RNAs alters their interaction with RBPs that function in nuclear RNA processing and cytosolic RNA localization or stability $[169,170]$. $\Psi$ modification also affects biogenesis of rRNAs, tRNAs, tRNA-derived small RNAs and snRNAs. Pseudouridylation of yeast and human mRNAs is regulated under stress conditions such as serum deprivation, $\mathrm{H}_{2} \mathrm{O}_{2}$ treatment and heat shock.

Several studies have illuminated the impact of pseudouridylation on neuronal functions. For instance, nociceptor neuron-specific loss of RluA-1 and RluA-2, which encode Drosophila PUS enzymes, causes hypersensitive nociception phenotypes such as thermal hyperalgesia [172]. Elevated amounts of $\Psi$ have been identified in the urine of AD patients, though this feature has not been symptomatically linked to AD [173]. deLonimier et al. have shown that $\Psi$ modification of the expanded intronic CCUG repeat in CNBP, expression of which is associated with type 2 myotonic dystrophy (DM2) in humans, results in reduced binding of muscleblind-like 1 protein to CCUG repeat-expanded CNBP RNA linked to DM2 pathogenicity [174]. Thus, pseudouridylation can be regarded as a therapeutic target for neurodegenerative diseases such as DM2. Abnormalities in PSU genes are known to cause neuronal dysfunction. For example, two point mutations in PUS1 were identified in a patient presenting with mild cognitive impairment and sideroblastic anemia since childhood, together with adult-onset hepatopathy, cardiomyopathy and insulin-dependent diabetes, all of which are typical clinical signs of myopathy-lactic acidosis-sideroblastic anemia (MLASA) syndrome [175]. Furthermore, observations of Pus3 mRNA expression in the nervous system of mouse embryos indicates a possible role for it in neuronal development, which is corroborated by a report linking PUS3 truncation to intellectual disability in human [176,177]. Mutations in PUS7 have been identified in human patients displaying intellectual disability, microcephaly, speech delay and aggressive behavior [178,179]. These mutations limit $\Psi$ modification at position 13 of tRNAs and reductions in PUS7-targeted mRNAs, with these phenotypes being recapitulated in Drosophila upon PUS7 knockout [178]. Moreover, higher expression levels of Dyskerin 1 (Dkc1) coding for a PUS component of the H/ACA-box snoRNP complex were observed in mouse embryonic neural tissues and specific neurons of the cerebellum and olfactory bulb of adult mouse brain, implying a potential role for it in neurodevelopment [180]. 


\subsection{RNA Editing}

RNA editing is a type of modification whereby adenosine (A) or cytosine (C) residues are converted to inosine (I) or uridine (U) residues, respectively. The C-to-U conversion was first noted in the mRNAs of mitochondrial cytochrome c oxidase subunit II (COX-2) of trypanosomes. In mammalian systems, it was first reported in the mRNA of hepatic apolipoprotein $B$, where it alters glutamate residue 2153 to a stop codon and results in formation of a truncated apolipoprotein B isoform known as Apo-B48 [181]. RNA editing is now known to be conserved from Drosophila to humans, and even operates in bacteria [182-185]. Most of the editing happens in the repetitive elements, such as primate-specific Alu repeats within introns or untranslated regions [186]. Besides that, a small number of editing events happen in coding regions or microRNA sequences [187-189]. A-to-I editing is catalyzed by adenosine deaminases (known as ADARs for Adenosine Deaminases Acting on $\underline{\text { RNA). Mammals }}$ have four ADARs-ADAR1p150, ADAR1p110, ADAR2 and ADAR3-generated from three ADAR genes (ADAR1-3), whereas Caenorhabditis elegans has two ADAR genes and Drosophila has only one $[190,191]$. Deamination of adenosines in tRNAs is accomplished by ADATs (Adenosine Deaminases Acting on $\underline{\mathrm{R} N \mathrm{R} A}$ ). Eukaryotes are reported to have three ADAT genes (ADAT1-3) [192]. Escherichia coli too has a tRNA-specific deaminase [193]. C-to-U editing is catalyzed by activation-induced cytidine deaminases/apolipoprotein B-editing complex (AID/APOBEC) [194,195]. The AID/APOBEC family of deaminases (AADs) in humans has 11 members. AADs are thought to have evolved from bacteria following lateral gene transfer and then diversified [196,197].

RNA editing exerts multiple functional impacts on RNA metabolism. A-to-I and C-to-U editing both influence RNA secondary structure [198,199]. RNA editing impacts gene expression by modulating the expression, processing or stability of miRNAs [200-202]. Importantly, A-to-I RNA editing is known to influence epitranscriptomic and proteomic diversity in cancers $[203,204]$.

RNA editing has a myriad of effects on brain functioning. A prominent role for RNA editing has been observed in the case of AMPA and Kainate glutamate receptors, whereby the glutamines $(Q)$ of $Q / R$ sites are replaced by arginine $(R)$. This change leads to $\mathrm{Ca}^{2+}$ impermeability and has been linked to the formation of long-term potentiation in synaptic plasticity. Absence of GluA2-Q/R editing results in epileptic seizures and death in mice due to uncontrolled $\mathrm{Ca}^{2+}$ influx [205]. A role for GluA2-Q/R editing in embryogenesis and in vitro differentiation of neural progenitor cells has also been reported [206]. Moreover, RNA editing has been linked to altered neuronal signal transduction, whereby editing at five closely-spaced but different sites of $5-\mathrm{HT}_{2 \mathrm{C}}$ serotonin receptor transcripts in human and rodents reduced the efficiency of G-protein coupling [206]. Evidence for RNA editing contributing to the generation of neuronal diversity in the fly brain comes from data showing ample editing events in the highly conserved regions of transcripts encoding channel proteins and other essential neuronal proteins [207]. This form of RNA modification also influences subunit assembly of the excitatory AMPA glutamate receptor and inhibitory $\mathrm{GABA}_{\mathrm{A}}$ receptor [206], and it regulates the activity of neuron-specific transcription factors such as glioma-associated oncogene 1 (GLI1) and Nova1 [208,209].

In humans, approximately $85 \%$ of all pre-mRNAs undergo A-to-I RNA editing $[186,210,211]$. This RNA modification underlies many neurological and neurodegenerative disorders. As stated above, epilepsy and related diseases are caused by dysregulated RNA editing of AMPA receptors. Similarly, ADAR2-mediated I/V site RNA editing of the potassium channel Kv1.1 has been linked to epilepsy. Mutations in KCNA1, which encodes Kv1.1, cause episodic ataxia type 1 (EA1), typically characterized by seizures, myokymia and ataxia. GluA2-Q/R site editing was found to be reduced in the motor neurons of ALS patients, which enhances $\mathrm{Ca}^{2+}$ influx and thereby elevates calpain activation to cleave more TDP-43, which is associated with mis-localization and cytoplasmic aggregation of TDP-43, a hallmark of ALS [212]. GluA2-Q/R editing efficiency at 30 different sites is reduced in the brains of AD patients [213]. Moreover, cerebral ischemia of CA1 pyramidal neurons significantly reduces RNA editing of AMPA receptors [212]. Psychiatric diseases such as 
schizophrenia and mood disorders have been linked to ADAR2-associated RNA editing of glutamate receptors [140] (see Table 2), and dysregulated editing of Htr $2 \mathrm{c}$ mRNA (encoding serotonin receptor subtype $5-\mathrm{HT}_{2 \mathrm{C}} \mathrm{R}$ ) may increase the propensity for suicide [212]. Notably, FMRP protein, the loss of which is responsible for FXS onset, regulates RNA editing by binding to the ADAR proteins of Drosophila [214], zebrafish [215], mice [216] and in human cell cultures [217]. Lastly an interesting report by Kawahara et al. related the effect of the editing of miRNA with an X-chromosome-linked human disorder characterized by gout and neurodevelopmental impairment with hyperuricemia. Their study revealed that tissue-specific A to I editing of miR-376 cluster transcripts resulted in targeting of a distinct set of genes by edited miRNA. Repression of one of the edited mature-miR-376 target genes, namely, phophoribosyl pyrophosphate synthetase 1, was implicated in tissue-specific regulation of uric acid levels [201]. Therefore, overall, RNA editing has been linked to diverse neurodevelopmental disorders such as Prader-Willi syndrome, ASD, FXS, and others.

\section{Conclusions}

With the rise of epitranscriptomics, another level of gene expression control beyond transcription, translation, and epigenetic regulation has emerged as one of the most interesting fields of research. Several studies have now shown that post-transcriptional RNA modifications play a significant role in the spatio-temporal expression of diverse proteins in the brain. Neural development from embryonic to adult stages, neurogenesis, and the maintenance of proper neuronal structure and functioning necessitate tightly controlled protein expression. RNA modification writers and erasers control the presence or absence of epitranscriptional marks such as m6A, m1A, m5C, $\Psi$ and RNA editing on diverse RNAs. Readers interpret these modifications to recruit RBPs that modulate RNA metabolic pathways, including splicing, mRNA decay, miRNA biogenesis, alternative polyadenylation, transport, and translation. In this way, RNA-modifying regulatory proteins and RBPs orchestrate the finely-tuned gene expression landscape to ensure appropriate brain development, structure and functioning. In neurodevelopmentally- and neurodegeneratively-diseased brains, these control mechanisms fail, likely due to diseasespecific mutations or abnormal aggregates that trap epitranscriptomic proteins. More extensive studies are now being undertaken in this field that will enrich our understanding of how RNA modifications and their regulatory proteins change under conditions of neurological/neurodegenerative disease.

Author Contributions: Conceptualization; P.M. and B.C.; writing-original draft preparation, P.M. and B.C.; writing-review and editing, P.M. and B.C.; project administration, P.M. and C.-K.J.S.; funding acquisition, C.-K.J.S. All authors have read and agreed to the published version of the manuscript.

Funding: This research received no external funding. The APC was funded by Ministry of Science and Technology, Taiwan. Grant Number: MOST 110-2320-B-038-088.

Acknowledgments: We thank John O'Brien for his help with editing this manuscript.

Conflicts of Interest: The authors declare no conflict of interest.

\section{References}

1. Liu, E.Y.; Cali, C.P.; Lee, E.B. RNA metabolism in neurodegenerative disease. Dis. Model Mech. 2017, 10, 509-518. [CrossRef] [PubMed]

2. Prashad, S.; Gopal, P.P. RNA-binding proteins in neurological development and disease. RNA Biol. 2021, 18, 972-987. [CrossRef] [PubMed]

3. Yano, M.; Hayakawa-Yano, Y.; Okano, H. RNA regulation went wrong in neurodevelopmental disorders: The example of Msi/Elavl RNA binding proteins. Int. J. Dev. Neurosci. 2016, 55, 124-130. [CrossRef] [PubMed]

4. Nussbacher, J.K.; Tabet, R.; Yeo, G.W.; Lagier-Tourenne, C. Disruption of RNA Metabolism in Neurological Diseases and Emerging Therapeutic Interventions. Neuron 2019, 102, 294-320. [CrossRef] [PubMed]

5. Schieweck, R.; Ninkovic, J.; Kiebler, M.A. RNA-binding proteins balance brain function in health and disease. Physiol. Rev. 2021, 101, 1309-1370. [CrossRef] [PubMed] 
6. $\quad$ Boccaletto, P.; Machnicka, M.A.; Purta, E.; Piatkowski, P.; Baginski, B.; Wirecki, T.K.; de Crecy-Lagard, V.; Ross, R.; Limbach, P.A.; Kotter, A.; et al. MODOMICS: A database of RNA modification pathways. 2017 update. Nucleic Acids Res. 2018, 46, D303-D307. [CrossRef] [PubMed]

7. Esteve-Puig, R.; Bueno-Costa, A.; Esteller, M. Writers, readers and erasers of RNA modifications in cancer. Cancer Lett. 2020, 474, 127-137. [CrossRef]

8. Jonkhout, N.; Tran, J.; Smith, M.A.; Schonrock, N.; Mattick, J.S.; Novoa, E.M. The RNA modification landscape in human disease. RNA 2017, 23, 1754-1769. [CrossRef]

9. Vuong, C.K.; Black, D.L.; Zheng, S. The neurogenetics of alternative splicing. Nat. Rev. Neurosci. 2016, 17, 265-281. [CrossRef]

10. Chabot, B.; Shkreta, L. Defective control of pre-messenger RNA splicing in human disease. J. Cell Biol. 2016, 212, 13-27. [CrossRef]

11. Faustino, N.A.; Cooper, T.A. Pre-mRNA splicing and human disease. Genes Dev. 2003, 17, 419-437. [CrossRef]

12. Mills, J.D.; Janitz, M. Alternative splicing of mRNA in the molecular pathology of neurodegenerative diseases. Neurobiol. Aging 2012, 33, 1012.e11-1012.e24. [CrossRef]

13. Li, D.; McIntosh, C.S.; Mastaglia, F.L.; Wilton, S.D.; Aung-Htut, M.T. Neurodegenerative diseases: A hotbed for splicing defects and the potential therapies. Transl. Neurodegener. 2021, 10, 16. [CrossRef]

14. Sanders, S.J.; Schwartz, G.B.; Farh, K.K. Clinical impact of splicing in neurodevelopmental disorders. Genome Med. 2020, 12, 36. [CrossRef]

15. Thacker, S.; Sefyi, M.; Eng, C. Alternative splicing landscape of the neural transcriptome in a cytoplasmic-predominant Pten expression murine model of autism-like Behavior. Transl. Psychiatry 2020, 10, 380. [CrossRef]

16. Dick, F.; Nido, G.S.; Alves, G.W.; Tysnes, O.B.; Nilsen, G.H.; Dolle, C.; Tzoulis, C. Differential transcript usage in the Parkinson's disease brain. PLoS Genet. 2020, 16, e1009182. [CrossRef]

17. Perrone, B.; La Cognata, V.; Sprovieri, T.; Ungaro, C.; Conforti, F.L.; Ando, S.; Cavallaro, S. Alternative Splicing of ALS Genes: Misregulation and Potential Therapies. Cell Mol. Neurobiol. 2020, 40, 1-14. [CrossRef]

18. Arnold, E.S.; Ling, S.C.; Huelga, S.C.; Lagier-Tourenne, C.; Polymenidou, M.; Ditsworth, D.; Kordasiewicz, H.B.; McAlonisDownes, M.; Platoshyn, O.; Parone, P.A.; et al. ALS-linked TDP-43 mutations produce aberrant RNA splicing and adult-onset motor neuron disease without aggregation or loss of nuclear TDP-43. Proc. Natl. Acad. Sci. USA 2013, 110, E736-E745. [CrossRef]

19. Schilling, J.; Broemer, M.; Atanassov, I.; Duernberger, Y.; Vorberg, I.; Dieterich, C.; Dagane, A.; Dittmar, G.; Wanker, E.; van Roon-Mom, W.; et al. Deregulated Splicing Is a Major Mechanism of RNA-Induced Toxicity in Huntington's Disease. J. Mol. Biol. 2019, 431, 1869-1877. [CrossRef]

20. Aikawa, T.; Watanabe, T.; Miyazaki, T.; Mikuni, T.; Wakamori, M.; Sakurai, M.; Aizawa, H.; Ishizu, N.; Watanabe, M.; Kano, M.; et al. Alternative splicing in the C-terminal tail of Cav2.1 is essential for preventing a neurological disease in mice. Hum. Mol. Genet. 2017, 26, 3094-3104. [CrossRef]

21. Tian, B.; Manley, J.L. Alternative polyadenylation of mRNA precursors. Nat. Rev. Mol. Cell Biol. 2017, 18, 18-30. [CrossRef]

22. Ren, F.; Zhang, N.; Zhang, L.; Miller, E.; Pu, J.J. Alternative Polyadenylation: A new frontier in post transcriptional regulation. Biomark. Res. 2020, 8, 67. [CrossRef]

23. Di Giammartino, D.C.; Nishida, K.; Manley, J.L. Mechanisms and consequences of alternative polyadenylation. Mol. Cell 2011, 43, 853-866. [CrossRef]

24. Tian, B.; Manley, J.L. Alternative cleavage and polyadenylation: The long and short of it. Trends Biochem. Sci. 2013, 38, 312-320. [CrossRef]

25. Derti, A.; Garrett-Engele, P.; Macisaac, K.D.; Stevens, R.C.; Sriram, S.; Chen, R.; Rohl, C.A.; Johnson, J.M.; Babak, T. A quantitative atlas of polyadenylation in five mammals. Genome Res. 2012, 22, 1173-1183. [CrossRef] [PubMed]

26. Hoque, M.; Ji, Z.; Zheng, D.; Luo, W.; Li, W.; You, B.; Park, J.Y.; Yehia, G.; Tian, B. Analysis of alternative cleavage and polyadenylation by $3^{\prime}$ region extraction and deep sequencing. Nat. Methods 2013, 10, 133-139. [CrossRef]

27. Shi, Y. Alternative polyadenylation: New insights from global analyses. RNA 2012, 18, 2105-2117. [CrossRef]

28. Zhang, H.; Lee, J.Y.; Tian, B. Biased alternative polyadenylation in human tissues. Genome Biol. 2005, 6, R100. [CrossRef]

29. Liu, D.; Brockman, J.M.; Dass, B.; Hutchins, L.N.; Singh, P.; McCarrey, J.R.; MacDonald, C.C.; Graber, J.H. Systematic variation in mRNA 3 '-processing signals during mouse spermatogenesis. Nucleic Acids Res. 2007, 35, 234-246. [CrossRef] [PubMed]

30. Nam, J.W.; Rissland, O.S.; Koppstein, D.; Abreu-Goodger, C.; Jan, C.H.; Agarwal, V.; Yildirim, M.A.; Rodriguez, A.; Bartel, D.P. Global analyses of the effect of different cellular contexts on microRNA targeting. Mol. Cell 2014, 53, 1031-1043. [CrossRef]

31. An, J.J.; Gharami, K.; Liao, G.Y.; Woo, N.H.; Lau, A.G.; Vanevski, F.; Torre, E.R.; Jones, K.R.; Feng, Y.; Lu, B.; et al. Distinct role of long $3^{\prime}$ UTR BDNF mRNA in spine morphology and synaptic plasticity in hippocampal neurons. Cell 2008, 134, 175-187. [CrossRef] [PubMed]

32. Berkovits, B.D.; Mayr, C. Alternative $3^{\prime}$ UTRs act as scaffolds to regulate membrane protein localization. Nature 2015, 522, 363-367. [CrossRef] [PubMed]

33. Luo, W.; Ji, Z.; Pan, Z.; You, B.; Hoque, M.; Li, W.; Gunderson, S.I.; Tian, B. The conserved intronic cleavage and polyadenylation site of CstF-77 gene imparts control of $3^{\prime}$ end processing activity through feedback autoregulation and by U1 snRNP. PLoS Genet. 2013, 9, e1003613. [CrossRef]

34. Braz, S.O.; Cruz, A.; Lobo, A.; Bravo, J.; Moreira-Ribeiro, J.; Pereira-Castro, I.; Freitas, J.; Relvas, J.B.; Summavielle, T.; Moreira, A. Expression of Rac1 alternative $3^{\prime}$ UTRs is a cell specific mechanism with a function in dendrite outgrowth in cortical neurons. Biochim. Biophys. Acta Gene Regul. Mech. 2017, 1860, 685-694. [CrossRef] 
35. Jereb, S.; Hwang, H.W.; Van Otterloo, E.; Govek, E.E.; Fak, J.J.; Yuan, Y.; Hatten, M.E.; Darnell, R.B. Differential $3^{\prime}$ Processing of Specific Transcripts Expands Regulatory and Protein Diversity Across Neuronal Cell Types. Elife 2018, 7, e34042. [CrossRef]

36. Yang, Y.; Paul, A.; Bach, T.N.; Huang, Z.J.; Zhang, M.Q. Single-cell alternative polyadenylation analysis delineates GABAergic neuron types. BMC Biol. 2021, 19, 144. [CrossRef]

37. Grassi, E.; Santoro, R.; Umbach, A.; Grosso, A.; Oliviero, S.; Neri, F.; Conti, L.; Ala, U.; Provero, P.; DiCunto, F.; et al. Choice of Alternative Polyadenylation Sites, Mediated by the RNA-Binding Protein Elavl3, Plays a Role in Differentiation of Inhibitory Neuronal Progenitors. Front. Cell Neurosci. 2018, 12, 518. [CrossRef]

38. Coutinho, A.M.; Oliveira, G.; Katz, C.; Feng, J.; Yan, J.; Yang, C.; Marques, C.; Ataide, A.; Miguel, T.S.; Borges, L.; et al. MECP2 coding sequence and 3'UTR variation in 172 unrelated autistic patients. Am. J. Med. Genet. B Neuropsychiatr. Genet. 2007, 144, 475-483. [CrossRef]

39. Hoffbuhr, K.; Devaney, J.M.; LaFleur, B.; Sirianni, N.; Scacheri, C.; Giron, J.; Schuette, J.; Innis, J.; Marino, M.; Philippart, M.; et al. MeCP2 mutations in children with and without the phenotype of Rett syndrome. Neurology 2001, 56, 1486-1495. [CrossRef]

40. Newnham, C.M.; Hall-Pogar, T.; Liang, S.; Wu, J.; Tian, B.; Hu, J.; Lutz, C.S. Alternative polyadenylation of MeCP2: Influence of cis-acting elements and trans-acting factors. RNA Biol. 2010, 7, 361-372. [CrossRef]

41. Shibayama, A.; Cook, E.H., Jr.; Feng, J.; Glanzmann, C.; Yan, J.; Craddock, N.; Jones, I.R.; Goldman, D.; Heston, L.L.; Sommer, S.S. MECP2 structural and 3'-UTR variants in schizophrenia, autism and other psychiatric diseases: A possible association with autism. Am. J. Med. Genet. B Neuropsychiatr. Genet. 2004, 128, 50-53. [CrossRef] [PubMed]

42. Tassone, F.; De Rubeis, S.; Carosi, C.; La Fata, G.; Serpa, G.; Raske, C.; Willemsen, R.; Hagerman, P.J.; Bagni, C. Differential usage of transcriptional start sites and polyadenylation sites in FMR1 premutation alleles. Nucleic Acids Res. 2011, 39, 6172-6185. [CrossRef] [PubMed]

43. Szkop, K.J.; Cooke, P.I.C.; Humphries, J.A.; Kalna, V.; Moss, D.S.; Schuster, E.F.; Nobeli, I. Dysregulation of Alternative Polyadenylation as a Potential Player in Autism Spectrum Disorder. Front. Mol. Neurosci. 2017, 10, 279. [CrossRef] [PubMed]

44. Gennarino, V.A.; Alcott, C.E.; Chen, C.A.; Chaudhury, A.; Gillentine, M.A.; Rosenfeld, J.A.; Parikh, S.; Wheless, J.W.; Roeder, E.R.; Horovitz, D.D.; et al. NUDT21-spanning CNVs lead to neuropsychiatric disease and altered MeCP2 abundance via alternative polyadenylation. Elife 2015, 4, e10782. [CrossRef]

45. Habib, R.; Noureen, N.; Nadeem, N. Decoding Common Features of Neurodegenerative Disorders: From Differentially Expressed Genes to Pathways. Curr. Genomic. 2018, 19, 300-312. [CrossRef]

46. Noori, A.; Mezlini, A.M.; Hyman, B.T.; Serrano-Pozo, A.; Das, S. Systematic review and meta-analysis of human transcriptomics reveals neuroinflammation, deficient energy metabolism, and proteostasis failure across neurodegeneration. Neurobiol. Dis. 2021, 149, 105225. [CrossRef]

47. Patel, R.; Brophy, C.; Hickling, M.; Neve, J.; Furger, A. Alternative cleavage and polyadenylation of genes associated with protein turnover and mitochondrial function are deregulated in Parkinson's, Alzheimer's and ALS disease. BMC Med. Genomics 2019, 12, 60. [CrossRef]

48. Rhinn, H.; Qiang, L.; Yamashita, T.; Rhee, D.; Zolin, A.; Vanti, W.; Abeliovich, A. Alternative alpha-synuclein transcript usage as a convergent mechanism in Parkinson's disease pathology. Nat. Commun. 2012, 3, 1084. [CrossRef]

49. Jenal, M.; Elkon, R.; Loayza-Puch, F.; van Haaften, G.; Kuhn, U.; Menzies, F.M.; Oude Vrielink, J.A.; Bos, A.J.; Drost, J.; Rooijers, K.; et al. The poly(A)-binding protein nuclear 1 suppresses alternative cleavage and polyadenylation sites. Cell 2012, 149, 538-553. [CrossRef]

50. Romo, L.; Ashar-Patel, A.; Pfister, E.; Aronin, N. Alterations in mRNA 3' UTR Isoform Abundance Accompany Gene Expression Changes in Human Huntington's Disease Brains. Cell Rep. 2017, 20, 3057-3070. [CrossRef]

51. Melamed, Z.; Lopez-Erauskin, J.; Baughn, M.W.; Zhang, O.; Drenner, K.; Sun, Y.; Freyermuth, F.; McMahon, M.A.; Beccari, M.S.; Artates, J.W.; et al. Premature polyadenylation-mediated loss of stathmin-2 is a hallmark of TDP-43-dependent neurodegeneration. Nat. Neurosci. 2019, 22, 180-190. [CrossRef]

52. Dickson, J.R.; Kruse, C.; Montagna, D.R.; Finsen, B.; Wolfe, M.S. Alternative polyadenylation and miR-34 family members regulate tau expression. J. Neurochem. 2013, 127, 739-749. [CrossRef]

53. Akbalik, G.; Schuman, E.M. Molecular biology. mRNA, live and unmasked. Science 2014, 343, 375-376. [CrossRef]

54. Nagano, S.; Jinno, J.; Abdelhamid, R.F.; Jin, Y.; Shibata, M.; Watanabe, S.; Hirokawa, S.; Nishizawa, M.; Sakimura, K.; Onodera, O.; et al. TDP-43 transports ribosomal protein mRNA to regulate axonal local translation in neuronal axons. Acta Neuropathol. 2020, 140, 695-713. [CrossRef]

55. Shigeoka, T.; Koppers, M.; Wong, H.H.; Lin, J.Q.; Cagnetta, R.; Dwivedy, A.; de Freitas Nascimento, J.; van Tartwijk, F.W.; Strohl, F.; Cioni, J.M.; et al. On-Site Ribosome Remodeling by Locally Synthesized Ribosomal Proteins in Axons. Cell Rep. 2019, 29, 3605-3619.e10. [CrossRef]

56. Richter, J.D.; Bassell, G.J.; Klann, E. Dysregulation and restoration of translational homeostasis in fragile X syndrome. Nat. Rev. Neurosci. 2015, 16, 595-605. [CrossRef]

57. Guedes-Dias, P.; Holzbaur, E.L.F. Axonal transport: Driving synaptic function. Science 2019, 366, eaaw9997. [CrossRef]

58. Nagano, S.; Araki, T. Axonal Transport and Local Translation of mRNA in Neurodegenerative Diseases. Front. Mol. Neurosci. 2021, 14, 697973. [CrossRef]

59. Banez-Coronel, M.; Ranum, L.P.W. Repeat-associated non-AUG (RAN) translation: Insights from pathology. Lab. Investig. 2019, 99, 929-942. [CrossRef] 
60. Cleary, J.D.; Pattamatta, A.; Ranum, L.P.W. Repeat-associated non-ATG (RAN) translation. J. Biol. Chem. 2018, 293, 16127-16141. [CrossRef]

61. Bagni, C.; Zukin, R.S. A Synaptic Perspective of Fragile X Syndrome and Autism Spectrum Disorders. Neuron 2019, 101, 1070-1088. [CrossRef]

62. Chu, J.F.; Majumder, P.; Chatterjee, B.; Huang, S.L.; Shen, C.J. TDP-43 Regulates Coupled Dendritic mRNA Transport-Translation Processes in Co-operation with FMRP and Staufen1. Cell Rep. 2019, 29, 3118-3133.e6. [CrossRef]

63. Majumder, P.; Chu, J.F.; Chatterjee, B.; Swamy, K.B.; Shen, C.J. Co-regulation of mRNA translation by TDP-43 and Fragile X Syndrome protein FMRP. Acta Neuropathol. 2016, 132, 721-738. [CrossRef]

64. Wang, E.T.; Taliaferro, J.M.; Lee, J.A.; Sudhakaran, I.P.; Rossoll, W.; Gross, C.; Moss, K.R.; Bassell, G.J. Dysregulation of mRNA Localization and Translation in Genetic Disease. J. Neurosci. 2016, 36, 11418-11426. [CrossRef]

65. Shukla, S.; Parker, R. Hypo- and Hyper-Assembly Diseases of RNA-Protein Complexes. Trends Mol. Med. 2016, 22, 615-628. [CrossRef]

66. Buchan, J.R.; Parker, R. Eukaryotic stress granules: The ins and outs of translation. Mol. Cell 2009, 36, 932-941. [CrossRef]

67. Wang, P.Y.; Lin, Y.M.; Wang, L.H.; Kuo, T.Y.; Cheng, S.J.; Wang, G.S. Reduced cytoplasmic MBNL1 is an early event in a brain-specific mouse model of myotonic dystrophy. Hum. Mol. Genet. 2017, 26, 2247-2257. [CrossRef]

68. Goodman, L.D.; Bonini, N.M. Repeat-associated non-AUG (RAN) translation mechanisms are running into focus for GGGGCCrepeat associated ALS/FTD. Prog. Neurobiol. 2019, 183, 101697. [CrossRef] [PubMed]

69. Ishiguro, T.; Nagai, Y.; Ishikawa, K. Insight Into Spinocerebellar Ataxia Type 31 (SCA31) From Drosophila Model. Front. Neurosci. 2021, 15, 472. [CrossRef] [PubMed]

70. Banez-Coronel, M.; Ayhan, F.; Tarabochia, A.D.; Zu, T.; Perez, B.A.; Tusi, S.K.; Pletnikova, O.; Borchelt, D.R.; Ross, C.A.; Margolis, R.L.; et al. RAN Translation in Huntington Disease. Neuron 2015, 88, 667-677. [CrossRef] [PubMed]

71. Zu, T.; Gibbens, B.; Doty, N.S.; Gomes-Pereira, M.; Huguet, A.; Stone, M.D.; Margolis, J.; Peterson, M.; Markowski, T.W.; Ingram, M.A.; et al. Non-ATG-initiated translation directed by microsatellite expansions. Proc. Natl. Acad. Sci. USA 2011, 108, 260-265. [CrossRef]

72. Eshraghi, M.; Karunadharma, P.P.; Blin, J.; Shahani, N.; Ricci, E.P.; Michel, A.; Urban, N.T.; Galli, N.; Sharma, M.; Ramirez-Jarquin, U.N.; et al. Mutant Huntingtin stalls ribosomes and represses protein synthesis in a cellular model of Huntington disease. Nat. Commun. 2021, 12, 1461. [CrossRef]

73. Akiyama, T.; Suzuki, N.; Ishikawa, M.; Fujimori, K.; Sone, T.; Kawada, J.; Funayama, R.; Fujishima, F.; Mitsuzawa, S.; Ikeda, K.; et al. Aberrant axon branching via Fos-B dysregulation in FUS-ALS motor neurons. EBioMedicine 2019, 45, 362-378. [CrossRef]

74. Imperatore, J.A.; McAninch, D.S.; Valdez-Sinon, A.N.; Bassell, G.J.; Mihailescu, M.R. FUS Recognizes G Quadruplex Structures Within Neuronal mRNAs. Front. Mol. Biosci. 2020, 7, 6. [CrossRef]

75. Inagaki, H.; Hosoda, N.; Tsuiji, H.; Hoshino, S.I. Direct evidence that Ataxin-2 is a translational activator mediating cytoplasmic polyadenylation. J. Biol. Chem. 2020, 295, 15810-15825. [CrossRef]

76. Montalbano, M.; McAllen, S.; Cascio, F.L.; Sengupta, U.; Garcia, S.; Bhatt, N.; Ellsworth, A.; Heidelman, E.A.; Johnson, O.D.; Doskocil, S.; et al. TDP-43 and Tau Oligomers in Alzheimer's Disease, Amyotrophic Lateral Sclerosis, and Frontotemporal Dementia. Neurobiol. Dis. 2020, 146, 105130. [CrossRef]

77. Houseley, J.; Tollervey, D. The many pathways of RNA degradation. Cell 2009, 136, 763-776. [CrossRef]

78. Chen, C.Y.; Ezzeddine, N.; Shyu, A.B. Messenger RNA half-life measurements in mammalian cells. Methods Enzymol. 2008, 448, 335-357.

79. Burow, D.A.; Umeh-Garcia, M.C.; True, M.B.; Bakhaj, C.D.; Ardell, D.H.; Cleary, M.D. Dynamic regulation of mRNA decay during neural development. Neural Dev. 2015, 10, 11. [CrossRef]

80. Porter, R.S.; Jaamour, F.; Iwase, S. Neuron-specific alternative splicing of transcriptional machineries: Implications for neurodevelopmental disorders. Mol. Cell Neurosci. 2018, 87, 35-45. [CrossRef]

81. Lee, S.; Wei, L.; Zhang, B.; Goering, R.; Majumdar, S.; Wen, J.; Taliaferro, J.M.; Lai, E.C. ELAV/Hu RNA binding proteins determine multiple programs of neural alternative splicing. PLoS Genet. 2021, 17, e1009439. [CrossRef]

82. DeBoer, E.M.; Azevedo, R.; Vega, T.A.; Brodkin, J.; Akamatsu, W.; Okano, H.; Wagner, G.C.; Rasin, M.R. Prenatal deletion of the RNA-binding protein HuD disrupts postnatal cortical circuit maturation and behavior. J. Neurosci. 2014, 34, 3674-3686. [CrossRef]

83. Berto, S.; Usui, N.; Konopka, G.; Fogel, B.L. ELAVL2-regulated transcriptional and splicing networks in human neurons link neurodevelopment and autism. Hum. Mol. Genet. 2016, 25, 2451-2464. [CrossRef]

84. Cha, I.J.; Lee, D.; Park, S.S.; Chung, C.G.; Kim, S.Y.; Jo, M.G.; Kim, S.Y.; Lee, B.H.; Lee, Y.S.; Lee, S.B. Ataxin-2 Dysregulation Triggers a Compensatory Fragile X Mental Retardation Protein Decrease in Drosophila C4da Neurons. Mol. Cells 2020, 43, 870-879.

85. Scheckel, C.; Drapeau, E.; Frias, M.A.; Park, C.Y.; Fak, J.; Zucker-Scharff, I.; Kou, Y.; Haroutunian, V.; Ma'ayan, A.; Buxbaum, J.D.; et al. Regulatory consequences of neuronal ELAV-like protein binding to coding and non-coding RNAs in human brain. Elife 2016, 5, e10421. [CrossRef]

86. Ostrowski, L.A.; Hall, A.C.; Mekhail, K. Ataxin-2: From RNA Control to Human Health and Disease. Genes 2017, 8, 157. [CrossRef]

87. Alkallas, R.; Fish, L.; Goodarzi, H.; Najafabadi, H.S. Inference of RNA decay rate from transcriptional profiling highlights the regulatory programs of Alzheimer's disease. Nat. Commun. 2017, 8, 909. [CrossRef] 
88. Costessi, L.; Porro, F.; Iaconcig, A.; Muro, A.F. TDP-43 regulates beta-adducin (Add2) transcript stability. RNA Biol. 2014, 11, 1280-1290. [CrossRef]

89. Wang, H.; Taguchi, Y.H.; Liu, X. Editorial: miRNAs and Neurological Diseases. Front. Neurol. 2021, 12, 662373. [CrossRef]

90. Guo, L.; Yin, M.; Wang, Y. CREB1, a direct target of miR-122, promotes cell proliferation and invasion in bladder cancer. Oncol. Lett. 2018, 16, 3842-3848. [CrossRef]

91. Jasinska, M.; Milek, J.; Cymerman, I.A.; Leski, S.; Kaczmarek, L.; Dziembowska, M. miR-132 Regulates Dendritic Spine Structure by Direct Targeting of Matrix Metalloproteinase 9 mRNA. Mol. Neurobiol. 2016, 53, 4701-4712. [CrossRef] [PubMed]

92. Rey, R.; Suaud-Chagny, M.F.; Dorey, J.M.; Teyssier, J.R.; d'Amato, T. Widespread transcriptional disruption of the microRNA biogenesis machinery in brain and peripheral tissues of individuals with schizophrenia. Transl. Psychiatry 2020, 10, 376. [CrossRef] [PubMed]

93. McKeever, P.M.; Schneider, R.; Taghdiri, F.; Weichert, A.; Multani, N.; Brown, R.A.; Boxer, A.L.; Karydas, A.; Miller, B.; Robertson, J.; et al. MicroRNA Expression Levels Are Altered in the Cerebrospinal Fluid of Patients with Young-Onset Alzheimer's Disease. Mol. Neurobiol. 2018, 55, 8826-8841. [CrossRef] [PubMed]

94. Riancho, J.; Vazquez-Higuera, J.L.; Pozueta, A.; Lage, C.; Kazimierczak, M.; Bravo, M.; Calero, M.; Gonalezalez, A.; Rodriguez, E.; Lleo, A.; et al. MicroRNA Profile in Patients with Alzheimer's Disease: Analysis of miR-9-5p and miR-598 in Raw and Exosome Enriched Cerebrospinal Fluid Samples. J. Alzheimers Dis. 2017, 57, 483-491. [CrossRef]

95. Rajgor, D. Macro roles for microRNAs in neurodegenerative diseases. Noncoding RNA Res. 2018, 3, 154-159. [CrossRef]

96. Rinchetti, P.; Rizzuti, M.; Faravelli, I.; Corti, S. MicroRNA Metabolism and Dysregulation in Amyotrophic Lateral Sclerosis. Mol. Neurobiol. 2018, 55, 2617-2630. [CrossRef]

97. Dong, X.; Cong, S. The Emerging Role of microRNAs in Polyglutamine Diseases. Front. Mol. Neurosci. 2019, 12, 156. [CrossRef]

98. Lopez Castel, A.; Overby, S.J.; Artero, R. MicroRNA-Based Therapeutic Perspectives in Myotonic Dystrophy. Int. J. Mol. Sci. 2019, 20, 5600. [CrossRef]

99. Parras, A.; Anta, H.; Santos-Galindo, M.; Swarup, V.; Elorza, A.; Nieto-Gonzalez, J.L.; Pico, S.; Hernandez, I.H.; Diaz-Hernandez, J.I.; Belloc, E.; et al. Autism-like phenotype and risk gene mRNA deadenylation by CPEB4 mis-splicing. Nature 2018, 560, 441-446. [CrossRef]

100. Carreira-Rosario, A.; Bhargava, V.; Hillebrand, J.; Kollipara, R.K.; Ramaswami, M.; Buszczak, M. Repression of Pumilio Protein Expression by Rbfox1 Promotes Germ Cell Differentiation. Dev. Cell 2016, 36, 562-571. [CrossRef]

101. Lee, J.A.; Damianov, A.; Lin, C.H.; Fontes, M.; Parikshak, N.N.; Anderson, E.S.; Geschwind, D.H.; Black, D.L.; Martin, K.C. Cytoplasmic Rbfox1 Regulates the Expression of Synaptic and Autism-Related Genes. Neuron 2016, 89, 113-128. [CrossRef]

102. Wei, C.; Xiao, R.; Chen, L.; Cui, H.; Zhou, Y.; Xue, Y.; Hu, J.; Zhou, B.; Tsutsui, T.; Qiu, J.; et al. RBFox2 Binds Nascent RNA to Globally Regulate Polycomb Complex 2 Targeting in Mammalian Genomes. Mol. Cell 2016, 62, 982. [CrossRef]

103. Lee, J.E.; Cooper, T.A. Pathogenic mechanisms of myotonic dystrophy. Biochem. Soc. Trans. 2009, 37 Pt 6, 1281-1286. [CrossRef]

104. Ramesh, N.; Daley, E.L.; Gleixner, A.M.; Mann, J.R.; Kour, S.; Mawrie, D.; Anderson, E.N.; Kofler, J.; Donnelly, C.J.; Kiskinis, E.; et al. RNA dependent suppression of C9orf72 ALS/FTD associated neurodegeneration by Matrin-3. Acta Neuropathol. Commun. 2020, 8, 177. [CrossRef]

105. Tan, M.S.; Yu, J.T.; Tan, L. Bridging integrator 1 (BIN1): Form, function, and Alzheimer's disease. Trends Mol. Med. 2013, 19, 594-603. [CrossRef]

106. Alami, N.H.; Smith, R.B.; Carrasco, M.A.; Williams, L.A.; Winborn, C.S.; Han, S.S.W.; Kiskinis, E.; Winborn, B.; Freibaum, B.D.; Kanagaraj, A.; et al. Axonal transport of TDP-43 mRNA granules is impaired by ALS-causing mutations. Neuron 2014, 81, 536-543. [CrossRef]

107. Coyne, A.N.; Yamada, S.B.; Siddegowda, B.B.; Estes, P.S.; Zaepfel, B.L.; Johannesmeyer, J.S.; Lockwood, D.B.; Pham, L.T.; Hart, M.P.; Cassel, J.A.; et al. Fragile X protein mitigates TDP-43 toxicity by remodeling RNA granules and restoring translation. Hum. Mol. Genet. 2015, 24, 6886-6898. [CrossRef]

108. Ling, S.C.; Albuquerque, C.P.; Han, J.S.; Lagier-Tourenne, C.; Tokunaga, S.; Zhou, H.; Cleveland, D.W. ALS-associated mutations in TDP-43 increase its stability and promote TDP-43 complexes with FUS/TLS. Proc. Natl. Acad. Sci. USA 2010, 107, 13318-13323. [CrossRef]

109. Lopez-Erauskin, J.; Tadokoro, T.; Baughn, M.W.; Myers, B.; McAlonis-Downes, M.; Chillon-Marinas, C.; Asiaban, J.N.; Artates, J.; Bui, A.T.; Vetto, A.P.; et al. ALS/FTD-Linked Mutation in FUS Suppresses Intra-axonal Protein Synthesis and Drives Disease Without Nuclear Loss-of-Function of FUS. Neuron 2018, 100, 816-830.e7. [CrossRef]

110. Sellier, C.; Rau, F.; Liu, Y.; Tassone, F.; Hukema, R.K.; Gattoni, R.; Schneider, A.; Richard, S.; Willemsen, R.; Elliott, D.J.; et al. Sam68 sequestration and partial loss of function are associated with splicing alterations in FXTAS patients. EMBO J. 2010, 29, 1248-1261. [CrossRef]

111. Conlon, E.G.; Manley, J.L. RNA-binding proteins in neurodegeneration: Mechanisms in aggregate. Genes Dev. 2017, 31, 1509-1528. [CrossRef]

112. Kelaini, S.; Chan, C.; Cornelius, V.A.; Margariti, A. RNA-Binding Proteins Hold Key Roles in Function, Dysfunction, and Disease. Biology 2021, 10, 366. [CrossRef]

113. Jung, Y.; Goldman, D. Role of RNA modifications in brain and behavior. Genes Brain Behav. 2018, 17, e12444. [CrossRef] [PubMed]

114. Sanchez-Vasquez, E.; Alata Jimenez, N.; Vazquez, N.A.; Strobl-Mazzulla, P.H. Emerging role of dynamic RNA modifications during animal development. Mech. Dev. 2018, 154, 24-32. [CrossRef] [PubMed] 
115. Yen, Y.P.; Chen, J.A. The m(6)A epitranscriptome on neural development and degeneration. J. Biomed. Sci. 2021, 28, 40. [CrossRef] [PubMed]

116. Yu, J.; Chen, M.; Huang, H.; Zhu, J.; Song, H.; Zhu, J.; Park, J.; Ji, S.J. Dynamic m6A modification regulates local translation of mRNA in axons. Nucleic Acids Res. 2018, 46, 1412-1423. [CrossRef] [PubMed]

117. Alarcon, C.R.; Lee, H.; Goodarzi, H.; Halberg, N.; Tavazoie, S.F. N6-methyladenosine marks primary microRNAs for processing. Nature 2015, 519, 482-485. [CrossRef] [PubMed]

118. Huang, H.; Weng, H.; Sun, W.; Qin, X.; Shi, H.; Wu, H.; Zhao, B.S.; Mesquita, A.; Liu, C.; Yuan, C.L.; et al. Recognition of RNA N(6)-methyladenosine by IGF2BP proteins enhances mRNA stability and translation. Nat. Cell Biol. 2018, 20, 285-295. [CrossRef] [PubMed]

119. Zhou, K.I.; Pan, T. An additional class of m(6)A readers. Nat. Cell Biol. 2018, 20, 230-232. [CrossRef]

120. Sokpor, G.; Xie, Y.; Nguyen, H.P.; Tuoc, T. Emerging Role of m(6) A Methylome in Brain Development: Implications for Neurological Disorders and Potential Treatment. Front. Cell Dev. Biol. 2021, 9, 656849. [CrossRef]

121. Livneh, I.; Moshitch-Moshkovitz, S.; Amariglio, N.; Rechavi, G.; Dominissini, D. The m(6)A epitranscriptome: Transcriptome plasticity in brain development and function. Nat. Rev. Neurosci. 2020, 21, 36-51. [CrossRef]

122. Han, M.; Liu, Z.; Xu, Y.; Liu, X.; Wang, D.; Li, F.; Wang, Y.; Bi, J. Abnormality of m6A mRNA Methylation Is Involved in Alzheimer's Disease. Front. Neurosci. 2020, 14, 98. [CrossRef]

123. Dermentzaki, G.; Lotti, F. New Insights on the Role of N (6)-Methyladenosine RNA Methylation in the Physiology and Pathology of the Nervous System. Front. Mol. Biosci. 2020, 7, 555372. [CrossRef]

124. Mendel, M.; Delaney, K.; Pandey, R.R.; Chen, K.M.; Wenda, J.M.; Vagbo, C.B.; Steiner, F.A.; Homolka, D.; Pillai, R.S. Splice site m(6)A methylation prevents binding of U2AF35 to inhibit RNA splicing. Cell 2021, 184, 3125-3142.e25. [CrossRef]

125. Shima, H.; Igarashi, K. N 1-methyladenosine (m1A) RNA modification: The key to ribosome control. J. Biochem. 2020, 167, 535-539. [CrossRef]

126. Roundtree, I.A.; Evans, M.E.; Pan, T.; He, C. Dynamic RNA Modifications in Gene Expression Regulation. Cell 2017, 169, 1187-1200. [CrossRef]

127. Zhang, C.; Jia, G. Reversible RNA Modification N(1)-methyladenosine (m(1)A) in mRNA and tRNA. Genomic. Proteomics Bioinform. 2018, 16, 155-161. [CrossRef]

128. Li, X.; Xiong, X.; Zhang, M.; Wang, K.; Chen, Y.; Zhou, J.; Mao, Y.; Lv, J.; Yi, D.; Chen, X.W.; et al. Base-Resolution Mapping Reveals Distinct m(1)A Methylome in Nuclear- and Mitochondrial-Encoded Transcripts. Mol. Cell 2017, 68, 993-1005.e9. [CrossRef]

129. Mathlin, J.; Le Pera, L.; Colombo, T. A Census and Categorization Method of Epitranscriptomic Marks. Int. J. Mol. Sci. 2020, 21, 4684. [CrossRef]

130. Safra, M.; Sas-Chen, A.; Nir, R.; Winkler, R.; Nachshon, A.; Bar-Yaacov, D.; Erlacher, M.; Rossmanith, W.; Stern-Ginossar, N.; Schwartz, S. The m1A landscape on cytosolic and mitochondrial mRNA at single-base resolution. Nature 2017, 551, 251-255. [CrossRef]

131. Liu, F.; Clark, W.; Luo, G.; Wang, X.; Fu, Y.; Wei, J.; Wang, X.; Hao, Z.; Dai, Q.; Zheng, G.; et al. ALKBH1-Mediated tRNA Demethylation Regulates Translation. Cell 2016, 167, 816-828.e16. [CrossRef]

132. Zheng, Q.; Gan, H.; Yang, F.; Yao, Y.; Hao, F.; Hong, L.; Jin, L. Cytoplasmic m(1)A reader YTHDF3 inhibits trophoblast invasion by downregulation of m(1)A-methylated IGF1R. Cell Discov. 2020, 6, 12. [CrossRef]

133. Satterlee, J.S.; Basanta-Sanchez, M.; Blanco, S.; Li, J.B.; Meyer, K.; Pollock, J.; Sadri-Vakili, G.; Rybak-Wolf, A. Novel RNA modifications in the nervous system: Form and function. J. Neurosci. 2014, 34, 15170-15177. [CrossRef]

134. Bohnsack, M.T.; Sloan, K.E. The mitochondrial epitranscriptome: The roles of RNA modifications in mitochondrial translation and human disease. Cell Mol. Life Sci. 2018, 75, 241-260. [CrossRef]

135. Kretschmer, J.; Rao, H.; Hackert, P.; Sloan, K.E.; Hobartner, C.; Bohnsack, M.T. The m(6)A reader protein YTHDC2 interacts with the small ribosomal subunit and the $5^{\prime}-3^{\prime}$ exoribonuclease XRN1. RNA 2018, 24, 1339-1350. [CrossRef]

136. Chan, C.T.Y.; Pang, Y.L.J.; Deng, W.J.; Babu, I.R.; Dyavaiah, M.; Begley, T.J.; Dedon, P.C. Reprogramming of tRNA modifications controls the oxidative stress response by codon-biased translation of proteins. Nat. Commun. 2012, 3, 1-9. [CrossRef]

137. Shanmugam, R.; Fierer, J.; Kaiser, S.; Helm, M.; Jurkowski, T.P.; Jeltsch, A. Cytosine methylation of tRNA-Asp by DNMT2 has a role in translation of proteins containing poly-Asp sequences. Cell Discov. 2015, 1, 1-10. [CrossRef]

138. Rai, K.; Chidester, S.; Zavala, C.V.; Manos, E.J.; James, S.R.; Karpf, A.R.; Jones, D.A.; Cairns, B.R. Dnmt2 functions in the cytoplasm to promote liver, brain, and retina development in zebrafish. Genes Dev. 2007, 21, 261-266. [CrossRef]

139. Boo, S.H.; Kim, Y.K. The emerging role of RNA modifications in the regulation of mRNA stability. Exp. Mol. Med. 2020, 52, 400-408. [CrossRef] [PubMed]

140. Kubota-Sakashita, M.; Iwamoto, K.; Bundo, M.; Kato, T. A role of ADAR2 and RNA editing of glutamate receptors in mood disorders and schizophrenia. Mol. Brain 2014, 7, 5. [CrossRef] [PubMed]

141. La Via, L.; Bonini, D.; Russo, I.; Orlandi, C.; Barlati, S.; Barbon, A. Modulation of dendritic AMPA receptor mRNA trafficking by RNA splicing and editing. Nucleic Acids Res. 2013, 41, 617-631. [CrossRef] [PubMed]

142. Yang, X.; Yang, Y.; Sun, B.F.; Chen, Y.S.; Xu, J.W.; Lai, W.Y.; Li, A.; Wang, X.; Bhattarai, D.P.; Xiao, W.; et al. 5-methylcytosine promotes mRNA export-NSUN2 as the methyltransferase and ALYREF as an m(5)C reader. Cell Res. 2017, 27, 606-625. [CrossRef] [PubMed] 
143. Schumann, U.; Zhang, H.N.; Sibbritt, T.; Pan, A.Y.; Horvath, A.; Gross, S.; Clark, S.J.; Yang, L.; Preiss, T. Multiple links between 5-methylcytosine content of mRNA and translation. BMC Biol. 2020, 18, 1-23. [CrossRef] [PubMed]

144. Yang, Y.; Wang, L.; Han, X.; Yang, W.L.; Zhang, M.M.; Ma, H.L.; Sun, B.F.; Li, A.; Xia, J.; Chen, J.; et al. RNA 5-Methylcytosine Facilitates the Maternal-to-Zygotic Transition by Preventing Maternal mRNA Decay. Mol. Cell 2019, 75, 1188-1202. [CrossRef] [PubMed]

145. David, R.; Burgess, A.; Parker, B.; Li, J.; Pulsford, K.; Sibbritt, T.; Preiss, T.; Searle, I.R. Transcriptome-Wide Mapping of RNA 5-Methylcytosine in Arabidopsis mRNAs and Noncoding RNAs. Plant Cell 2017, 29, 445-460. [CrossRef]

146. Xue, S.L.; Xu, H.; Sun, Z.; Shen, H.; Chen, S.H.; Ouyang, J.; Zhou, Q.Q.; Hu, X.M.; Cui, H.M. Depletion of TRDMT1 affects 5-methylcytosine modification of mRNA and inhibits HEK293 cell proliferation and migration. Biochem. Biophys. Res. Commun. 2019, 520, 60-66. [CrossRef]

147. Hussain, S.; Sajini, A.A.; Blanco, S.; Dietmann, S.; Lombard, P.; Sugimoto, Y.; Paramor, M.; Gleeson, J.G.; Odom, D.T.; Ule, J.; et al. NSun2-Mediated Cytosine-5 Methylation of Vault Noncoding RNA Determines Its Processing into Regulatory Small RNAs. Cell Rep. 2013, 4, 255-261. [CrossRef]

148. Reid, R.; Greene, P.J.; Santi, D.V. Exposition of a family of RNA m(5)C methyltransferases from searching genomic and proteomic sequences. Nucleic Acids Res. 1999, 27, 3138-3145. [CrossRef]

149. Bohnsack, K.E.; Hobartner, C.; Bohnsack, M.T. Eukaryotic 5-methylcytosine (m(5)C) RNA Methyltransferases: Mechanisms, Cellular Functions, and Links to Disease. Genes 2019, 10, 102. [CrossRef]

150. Van Haute, L.; Lee, S.Y.; McCann, B.J.; Powell, C.A.; Bansal, D.; Vasiliauskaite, L.; Garone, C.; Shin, S.; Kim, J.S.; Frye, M.; et al. NSUN2 introduces 5-methylcytosines in mammalian mitochondrial tRNAs. Nucleic Acids Res. 2019, 47, 8720-8733. [CrossRef]

151. Aguilo, F.; Li, S.D.; Balasubramaniyan, N.; Sancho, A.; Benko, S.; Zhang, F.; Vashisht, A.; Rengasamy, M.; Andino, B.; Chen, C.H.; et al. Deposition of 5-Methylcytosine on Enhancer RNAs Enables the Coactivator Function of PGC-1 alpha. Cell Rep. 2016, 14, 479-492. [CrossRef]

152. Liu, Y.Q.; Santi, D.V. m(5)C RNA and m(5)C DNA methyl transferases use different cysteine residues as catalysts. Proc. Natl. Acad. Sci. USA 2000, 97, 8263-8265. [CrossRef]

153. King, M.Y.; Redman, K.L. RNA Methyltransferases utilize two cysteine residues in the formation of 5-methylcytosine. Biochemistry 2002, 41, 11218-11225. [CrossRef]

154. Huang, W.; Lan, M.D.; Qi, C.B.; Zheng, S.J.; Wei, S.Z.; Yuan, B.F.; Feng, Y.Q. Formation and determination of the oxidation products of 5-methylcytosine in RNA. Chem. Sci. 2016, 7, 5495-5502. [CrossRef]

155. Schosserer, M.; Minois, N.; Angerer, T.B.; Amring, M.; Dellago, H.; Harreither, E.; Calle-Perez, A.; Pircher, A.; Gerstl, M.P.; Pfeifenberger, S.; et al. Methylation of ribosomal RNA by NSUN5 is a conserved mechanism modulating organismal lifespan. Nat. Commun. 2015, 6, 1-7. [CrossRef]

156. Tuorto, F.; Herbst, F.; Alerasool, N.; Bender, S.; Popp, O.; Federico, G.; Reitter, S.; Liebers, R.; Stoecklin, G.; Grone, H.J.; et al. The tRNA methyltransferase Dnmt2 is required for accurate polypeptide synthesis during haematopoiesis. EMBO J. 2015, 34, 2350-2362. [CrossRef]

157. Cui, X.A.; Liang, Z.; Shen, L.S.; Zhang, Q.; Bao, S.J.; Geng, Y.K.; Zhang, B.; Leo, V.; Vardy, L.A.; Lu, T.G.; et al. 5-Methylcytosine RNA Methylation in \&ITArabidopsis Thaliana\&IT. Mol. Plant. 2017, 10, 1387-1399.

158. Huang, T.; Chen, W.; Liu, J.; Gu, N.; Zhang, R. Genome-wide identification of mRNA 5-methylcytosine in mammals. Nat. Struct. Mol. Biol. 2019, 26, 380-388. [CrossRef]

159. Li, Q.; Li, X.; Tang, H.; Jiang, B.; Dou, Y.; Gorospe, M.; Wang, W. NSUN2-Mediated m5C Methylation and METTL3/METTL14Mediated m6A Methylation Cooperatively Enhance p21 Translation. J. Cell Biochem. 2017, 118, 2587-2598. [CrossRef]

160. Blanco, S.; Frye, M. Role of RNA methyltransferases in tissue renewal and pathology. Curr. Opin. Cell Biol. $2014,31,1-7$. [CrossRef]

161. Blanco, S.; Kurowski, A.; Nichols, J.; Watt, F.M.; Benitah, S.A.; Frye, M. The RNA-Methyltransferase Misu (NSun2) Poises Epidermal Stem Cells to Differentiate. PLoS Genet. 2011, 7, e1002403. [CrossRef]

162. Hussain, S.; Tuorto, F.; Menon, S.; Blanco, S.; Cox, C.; Flores, J.V.; Watt, S.; Kudo, N.R.; Lyko, F.; Frye, M. The Mouse Cytosine-5 RNA Methyltransferase NSun2 Is a Component of the Chromatoid Body and Required for Testis Differentiation. Mol. Cell Biol. 2013, 33, 1561-1570. [CrossRef]

163. Khan, M.A.; Rafiq, M.A.; Noor, A.; Hussain, S.; Flores, J.V.; Rupp, V.; Vincent, A.K.; Malli, R.; Ali, G.; Khan, F.S.; et al. Mutation in NSUN2, which Encodes an RNA Methyltransferase, Causes Autosomal-Recessive Intellectual Disability. Am. J. Hum. Genet. 2012, 90, 856-863. [CrossRef]

164. Abbasi-Moheb, L.; Mertel, S.; Gonsior, M.; Nouri-Vahid, L.; Kahrizi, K.; Cirak, S.; Wieczorek, D.; Motazacker, M.M.; Esmaeeli-Nieh, S.; Cremer, K.; et al. Mutations in NSUN2 Cause Autosomal-Recessive Intellectual Disability. Am. J. Hum. Genet. 2012, 90, 847-855. [CrossRef] [PubMed]

165. Martinez, F.J.; Lee, J.H.; Lee, J.E.; Blanco, S.; Nickerson, E.; Gabriel, S.; Frye, M.; Al-Gazali, L.; Gleeson, J.G. Whole exome sequencing identifies a splicing mutation in NSUN2 as a cause of a Dubowitz-like syndrome. J. Med. Genet. 2012, 49, 380-385. [CrossRef]

166. Blaze, J.; Navickas, A.; Phillips, H.L.; Heissel, S.; Plaza-Jennings, A.; Miglani, S.; Asgharian, H.; Foo, M.; Katanski, C.D.; Watkins, C.P.; et al. Neuronal Nsun2 deficiency produces tRNA epitranscriptomic alterations and proteomic shifts impacting synaptic signaling and behavior. Nat. Commun. 2021, 12, 1-16. [CrossRef] 
167. Flores, J.V.; Cordero-Espinoza, L.; Oeztuerk-Winder, F.; Andersson-Rolf, A.; Selmi, T.; Blanco, S.; Tailor, J.; Dietmann, S.; Frye, M. Cytosine-5 RNA Methylation Regulates Neural Stem Cell Differentiation and Motility. Stem Cell Rep. 2017, 8, 112-124. [CrossRef] [PubMed]

168. Van Haute, L.; Dietmann, S.; Kremer, L.; Hussain, S.; Pearce, S.F.; Powell, C.A.; Rorbach, J.; Lantaff, R.; Blanco, S.; Sauer, S.; et al. Deficient methylation and formylation of mt- tRNA(Met) wobble cytosine in a patient carrying mutations in NSUN3. Nat. Commun. 2016, 7, 1-10. [CrossRef] [PubMed]

169. Borchardt, E.K.; Martinez, N.M.; Gilbert, W.V. Regulation and Function of RNA Pseudouridylation in Human Cells. Annu. Rev. Genet. 2020, 54, 309-336. [CrossRef] [PubMed]

170. Angelova, M.T.; Dimitrova, D.G.; Dinges, N.; Lence, T.; Worpenberg, L.; Carre, C.; Roignant, J.Y. The Emerging Field of Epitranscriptomics in Neurodevelopmental and Neuronal Disorders. Front. Bioeng. Biotechnol. 2018, 6, 46. [CrossRef] [PubMed]

171. Nainar, S.; Marshall, P.R.; Tyler, C.R.; Spitale, R.C.; Bredy, T.W. Evolving insights into RNA modifications and their functional diversity in the brain. Nat. Neurosci. 2016, 19, 1292-1298. [CrossRef]

172. Song, W.; Ressl, S.; Tracey, W.D. Loss of Pseudouridine Synthases in the RluA Family Causes Hypersensitive Nociception in Drosophila. G3-Genes Genomes Genet. 2020, 10, 4425-4438. [CrossRef]

173. Lee, S.H.; Kim, I.; Chung, B.C. Increased urinary level of oxidized nucleosides in patients with mild-to-moderate Alzheimer's disease. Clin. Biochem. 2007, 40, 936-938. [CrossRef]

174. Delorimier, E.; Hinman, M.N.; Copperman, J.; Datta, K.; Guenza, M.; Berglund, J.A. Pseudouridine Modification Inhibits Muscleblind-like 1 (MBNL1) Binding to CCUG Repeats and Minimally Structured RNA through Reduced RNA Flexibility. J. Biol. Chem. 2017, 292, 4350-4357. [CrossRef]

175. Cao, M.; Dona, M.; Valentino, L.; Semplicini, C.; Maresca, A.; Cassina, M.; Torraco, A.; Galletta, E.; Manfioli, V.; Soraru, G.; et al. Clinical and molecular study in a long-surviving patient with MLASA syndrome due to novel PUS1 mutations. Neurogenetics 2016, 17, 65-70. [CrossRef]

176. Diez-Roux, G.; Banfi, S.; Sultan, M.; Geffers, L.; Anand, S.; Rozado, D.; Magen, A.; Canidio, E.; Pagani, M.; Peluso, I.; et al. A High-Resolution Anatomical Atlas of the Transcriptome in the Mouse Embryo. PLoS Biol. 2011, 9, e1000582. [CrossRef]

177. Shaheen, R.; Han, L.; Faqeih, E.; Ewida, N.; Alobeid, E.; Phizicky, E.M.; Alkuraya, F.S. A homozygous truncating mutation in PUS3 expands the role of tRNA modification in normal cognition. Hum. Genet. 2016, 135, 707-713. [CrossRef]

178. De Brouwer, A.P.M.; Abou Jamra, R.; Kortel, N.; Soyris, C.; Polla, D.L.; Safra, M.; Zisso, A.; Powell, C.A.; Rebelo-Guiomar, P.; Dinges, N.; et al. Variants in PUS7 Cause Intellectual Disability with Speech Delay, Microcephaly, Short Stature, and Aggressive Behavior. Am. J. Hum. Genet. 2018, 103, 1045-1052. [CrossRef]

179. Shaheen, R.; Tasak, M.; Maddirevula, S.; Abdel-Salam, G.M.H.; Sayed, I.S.M.; Alazami, A.M.; Al-Sheddi, T.; Alobeid, E.; Phizicky, E.M.; Alkuraya, F.S. PUS7 mutations impair pseudouridylation in humans and cause intellectual disability and microcephaly. Hum. Genet. 2019, 138, 231-239. [CrossRef]

180. Heiss, N.S.; Bachner, D.; Salowsky, R.; Kolb, A.; Kioschis, P.; Poustka, A. Gene structure and expression of the mouse dyskeratosis congenita gene, Dkc1. Genomics 2000, 67, 153-163. [CrossRef]

181. Christofi, T.; Zaravinos, A. RNA editing in the forefront of epitranscriptomics and human health. J. Transl. Med. 2019, 17, 319. [CrossRef] [PubMed]

182. Bar-Yaacov, D.; Mordret, E.; Towers, R.; Biniashvili, T.; Soyris, C.; Schwartz, S.; Dahan, O.; Pilpel, Y. RNA editing in bacteria recodes multiple proteins and regulates an evolutionarily conserved toxin-antitoxin system. Genome Res. 2017, 27, 1696-1703. [CrossRef] [PubMed]

183. Grice, L.F.; Degnan, B.M. The origin of the ADAR gene family and animal RNA editing. BMC Evol. Biol. 2015, 15, 4. [CrossRef] [PubMed]

184. Keegan, L.P.; McGurk, L.; Palavicini, J.P.; Brindle, J.; Paro, S.; Li, X.; Rosenthal, J.J.; O'Connell, M.A. Functional conservation in human and Drosophila of Metazoan ADAR2 involved in RNA editing: Loss of ADAR1 in insects. Nucleic Acids Res. 2011, 39, 7249-7262. [CrossRef] [PubMed]

185. Slavov, D.; Crnogorac-Jurcevic, T.; Clark, M.; Gardiner, K. Comparative analysis of the DRADA A-to-I RNA editing gene from mammals, pufferfish and zebrafish. Gene 2000, 250, 53-60. [CrossRef]

186. Athanasiadis, A.; Rich, A.; Maas, S. Widespread A-to-I RNA editing of Alu-containing mRNAs in the human transcriptome. PLoS Biol. 2004, 2, e391. [CrossRef] [PubMed]

187. Jinnah, H.; Ulbricht, R.J. Using mouse models to unlock the secrets of non-synonymous RNA editing. Methods 2019, 156, 40-45. [CrossRef]

188. Kawahara, Y.; Megraw, M.; Kreider, E.; Iizasa, H.; Valente, L.; Hatzigeorgiou, A.G.; Nishikura, K. Frequency and fate of microRNA editing in human brain. Nucleic Acids Res. 2008, 36, 5270-5280. [CrossRef]

189. Nishikura, K. A-to-I editing of coding and non-coding RNAs by ADARs. Nat. Rev. Mol. Cell Biol. 2016, 17, 83-96. [CrossRef]

190. Tonkin, L.A.; Saccomanno, L.; Morse, D.P.; Brodigan, T.; Krause, M.; Bass, B.L. RNA editing by ADARs is important for normal behavior in Caenorhabditis elegans. EMBO J. 2002, 21, 6025-6035. [CrossRef]

191. Palladino, M.J.; Keegan, L.P.; O'Connell, M.A.; Reenan, R.A. dADAR, a Drosophila double-stranded RNA-specific adenosine deaminase is highly developmentally regulated and is itself a target for RNA editing. RNA 2000, 6, 1004-1018. [CrossRef]

192. Torres, A.G.; Pineyro, D.; Filonava, L.; Stracker, T.H.; Batlle, E.; Ribas de Pouplana, L. A-to-I editing on tRNAs: Biochemical, biological and evolutionary implications. FEBS Lett. 2014, 588, 4279-4286. [CrossRef] 
193. Wolf, J.; Gerber, A.P.; Keller, W. tadA, an essential tRNA-specific adenosine deaminase from Escherichia coli. EMBO J. 2002, 21, 3841-3851. [CrossRef]

194. Knisbacher, B.A.; Gerber, D.; Levanon, E.Y. DNA Editing by APOBECs: A Genomic Preserver and Transformer. Trends Genet. 2016, 32, 16-28. [CrossRef]

195. Smith, H.C.; Bennett, R.P.; Kizilyer, A.; McDougall, W.M.; Prohaska, K.M. Functions and regulation of the APOBEC family of proteins. Semin. Cell Dev. Biol. 2012, 23, 258-268. [CrossRef]

196. Krishnan, A.; Iyer, L.M.; Holland, S.J.; Boehm, T.; Aravind, L. Diversification of AID/APOBEC-like deaminases in metazoa: Multiplicity of clades and widespread roles in immunity. Proc. Natl. Acad. Sci. USA 2018, 115, E3201-E3210. [CrossRef]

197. Iyer, L.M.; Zhang, D.; Rogozin, I.B.; Aravind, L. Evolution of the deaminase fold and multiple origins of eukaryotic editing and mutagenic nucleic acid deaminases from bacterial toxin systems. Nucleic Acids Res. 2011, 39, 9473-9497. [CrossRef]

198. Wang, I.X.; So, E.; Devlin, J.L.; Zhao, Y.; Wu, M.; Cheung, V.G. ADAR regulates RNA editing, transcript stability, and gene expression. Cell Rep. 2013, 5, 849-860. [CrossRef]

199. Solomon, O.; Di Segni, A.; Cesarkas, K.; Porath, H.T.; Marcu-Malina, V.; Mizrahi, O.; Stern-Ginossar, N.; Kol, N.; Farage-Barhom, S.; Glick-Saar, E.; et al. RNA editing by ADAR1 leads to context-dependent transcriptome-wide changes in RNA secondary structure. Nat. Commun. 2017, 8, 1440. [CrossRef]

200. Correia de Sousa, M.; Gjorgjieva, M.; Dolicka, D.; Sobolewski, C.; Foti, M. Deciphering miRNAs' Action through miRNA Editing. Int. J. Mol. Sci. 2019, 20, 6249. [CrossRef]

201. Kawahara, Y.; Zinshteyn, B.; Sethupathy, P.; Iizasa, H.; Hatzigeorgiou, A.G.; Nishikura, K. Redirection of silencing targets by adenosine-to-inosine editing of miRNAs. Science 2007, 315, 1137-1140. [CrossRef]

202. Yang, W.; Chendrimada, T.P.; Wang, Q.; Higuchi, M.; Seeburg, P.H.; Shiekhattar, R.; Nishikura, K. Modulation of microRNA processing and expression through RNA editing by ADAR deaminases. Nat. Struct. Mol. Biol. 2006, 13, 13-21. [CrossRef]

203. Gassner, F.J.; Zaborsky, N.; Buchumenski, I.; Levanon, E.Y.; Gatterbauer, M.; Schubert, M.; Rauscher, S.; Hebenstreit, D.; Nadeu, F.; Campo, E.; et al. RNA editing contributes to epitranscriptome diversity in chronic lymphocytic leukemia. Leukemia 2021, 35, 1053-1063. [CrossRef]

204. Peng, X.; Xu, X.; Wang, Y.; Hawke, D.H.; Yu, S.; Han, L.; Zhou, Z.; Mojumdar, K.; Jeong, K.J.; Labrie, M.; et al. A-to-I RNA Editing Contributes to Proteomic Diversity in Cancer. Cancer Cell 2018, 33, 817-828.e7. [CrossRef]

205. Konen, L.M.; Wright, A.L.; Royle, G.A.; Morris, G.P.; Lau, B.K.; Seow, P.W.; Zinn, R.; Milham, L.T.; Vaughan, C.W.; Vissel, B. A new mouse line with reduced GluA2 Q/R site RNA editing exhibits loss of dendritic spines, hippocampal CA1-neuron loss, learning and memory impairments and NMDA receptor-independent seizure vulnerability. Mol. Brain 2020, 13, 27. [CrossRef]

206. Behm, M.; Ohman, M. RNA Editing: A Contributor to Neuronal Dynamics in the Mammalian Brain. Trends Genet. 2016, 32, 165-175. [CrossRef]

207. Sapiro, A.L.; Shmueli, A.; Henry, G.L.; Li, Q.; Shalit, T.; Yaron, O.; Paas, Y.; Billy Li, J.; Shohat-Ophir, G. Illuminating spatial A-to-I RNA editing signatures within the Drosophila brain. Proc. Natl. Acad. Sci. USA 2019, 116, 2318-2327. [CrossRef]

208. Shimokawa, T.; Rahman, M.F.; Tostar, U.; Sonkoly, E.; Stahle, M.; Pivarcsi, A.; Palaniswamy, R.; Zaphiropoulos, P.G. RNA editing of the GLI1 transcription factor modulates the output of Hedgehog signaling. RNA Biol. 2013, 10, 321-333. [CrossRef]

209. Zhang, C.; Frias, M.A.; Mele, A.; Ruggiu, M.; Eom, T.; Marney, C.B.; Wang, H.; Licatalosi, D.D.; Fak, J.J.; Darnell, R.B. Integrative modeling defines the Nova splicing-regulatory network and its combinatorial controls. Science 2010, 329, 439-443. [CrossRef]

210. Bazak, L.; Haviv, A.; Barak, M.; Jacob-Hirsch, J.; Deng, P.; Zhang, R.; Isaacs, F.J.; Rechavi, G.; Li, J.B.; Eisenberg, E.; et al. A-to-I RNA editing occurs at over a hundred million genomic sites, located in a majority of human genes. Genome Res. 2014, 24, 365-376. [CrossRef]

211. Tan, M.H.; Li, Q.; Shanmugam, R.; Piskol, R.; Kohler, J.; Young, A.N.; Liu, K.I.; Zhang, R.; Ramaswami, G.; Ariyoshi, K.; et al. Dynamic landscape and regulation of RNA editing in mammals. Nature 2017, 550, 249-254. [CrossRef] [PubMed]

212. Costa Cruz, P.H.; Kawahara, Y. RNA Editing in Neurological and Neurodegenerative Disorders. Methods Mol. Biol. 2021, 2181, 309-330. [PubMed]

213. Khermesh, K.; D’Erchia, A.M.; Barak, M.; Annese, A.; Wachtel, C.; Levanon, E.Y.; Picardi, E.; Eisenberg, E. Reduced levels of protein recoding by A-to-I RNA editing in Alzheimer's disease. RNA 2016, 22, 290-302. [CrossRef] [PubMed]

214. Bhogal, B.; Jepson, J.E.; Savva, Y.A.; Pepper, A.S.; Reenan, R.A.; Jongens, T.A. Modulation of dADAR-dependent RNA editing by the Drosophila fragile $X$ mental retardation protein. Nat. Neurosci. 2011, 14, 1517-1524. [CrossRef] [PubMed]

215. Shamay-Ramot, A.; Khermesh, K.; Porath, H.T.; Barak, M.; Pinto, Y.; Wachtel, C.; Zilberberg, A.; Lerer-Goldshtein, T.; Efroni, S.; Levanon, E.Y.; et al. Fmrp Interacts with Adar and Regulates RNA Editing, Synaptic Density and Locomotor Activity in Zebrafish. PLoS Genet. 2015, 11, e1005702. [CrossRef]

216. Filippini, A.; Bonini, D.; Lacoux, C.; Pacini, L.; Zingariello, M.; Sancillo, L.; Bosisio, D.; Salvi, V.; Mingardi, J.; La Via, L.; et al. Absence of the Fragile X Mental Retardation Protein results in defects of RNA editing of neuronal mRNAs in mouse. RNA Biol. 2017, 14, 1580-1591. [CrossRef]

217. Tran, S.S.; Jun, H.I.; Bahn, J.H.; Azghadi, A.; Ramaswami, G.; Van Nostrand, E.L.; Nguyen, T.B.; Hsiao, Y.E.; Lee, C.; Pratt, G.A.; et al. Widespread RNA editing dysregulation in brains from autistic individuals. Nat. Neurosci. 2019, 22, 25-36. [CrossRef] 